\title{
Diterpenes from the Marine Algae of the Genus Dictyota
}

\author{
Jiayun Chen ${ }^{1}$, Hong $\mathrm{Li}^{1}{ }^{1}$, Zishuo Zhao ${ }^{1}$, Xue Xia ${ }^{1}$, Bo Li ${ }^{1}$, Jinrong Zhang ${ }^{1, *}$ and Xiaojun Yan ${ }^{2, *}$ \\ 1 Laboratory of Marine Natural Products, School of Marine Sciences, Ningbo University, Ningbo 315211, \\ China; chenjiayun1030@163.com (J.C.); lih19921020@gmail.com (H.L.); zhaozishuo1102@163.com (Z.Z.); \\ xiaxue980106@163.com (X.X.); lib980419@163.com (B.L.) \\ 2 Key Laboratory of Applied Marine Biotechnology of Ministry of Education, Ningbo University, \\ Ningbo 315211, China \\ * Correspondence: zhangjinrong@nbu.edu.cn (J.Z.); yanxiaojun@nbu.edu.cn (X.Y.); \\ Tel./Fax: +86-574-8760-0458 (J.Z.); +86-574-8760-0556 (X.Y.)
}

Received: 23 April 2018; Accepted: 7 May 2018; Published: 11 May 2018

\begin{abstract}
Species of the brown algae of the genus Dictyota are rich sources of bioactive secondary metabolites with diverse structural features. Excellent progress has been made in the discovery of diterpenes possessing broad chemical defensive activities from this genus. Most of these diterpenes exhibit significant biological activities, such as antiviral, cytotoxic and chemical defensive activities. In the present review, we summarized diterpenes isolated from the brown algae of the genus.
\end{abstract}

Keywords: Dictyota; diterpene; secondary metabolites; bioactivity

\section{Introduction}

Marine brown algae of the genus Dictyota, belonging to the family Dictyotaceae, are mainly distributed in subtropical and tropical oceans [1]. Structurally diverse secondary metabolites from members of this genus were found to possess a defensive property which greatly contributes to their successful survival and reproduction in complex and diverse marine environments [2]. At present, hundreds of bioactive natural products, including terpenes, phenols [3], sterols [4], fatty acids [5], and polysaccharides [6], have been isolated from marine brown algae of the genus Dictyota. Diterpenes are a large class of structurally diverse natural products which are widely found in marine organisms, including Dictyota species [7]. Some diterpenes are promising drug candidates due to their remarkable pharmacological activity [8-10]. Some diterpenes from Dictyota species are considered as the characteristic constituents of this genus, and give them taxonomic significance [1,11]. Diterpenes from members of this genus usually exhibit potent cytotoxic or antiviral activities [12,13].

In the present review, we systematically summarize the structures and bioactivities of diterpenes derived from members of the genus Dictyota, with more than 80 references cited. Up to the end of 2017, a total of 233 diterpenes had been isolated from Dictyota species, most of which were from the marine brown alga Dictyota dichotoma. It has been reported that many of these diterpenes possess several interesting bioactivities, including cytotoxic and antiviral activities.

\section{Diterpenes of Group I}

Based on the revised biogenetic scheme widely cited, the diterpenes from Dictyota species can be divided into three groups (I-III), resulting from the first formal cyclization of the geranyl-geraniol precursor. Group 1 contains diterpenes derived by the first cyclization of the geranyl-geraniol precursor between C-1 and C-10 [1]. Diterpenes of Group 1 are mainly prenylated derivatives of known sesquiterpene skeletons, including prenylated-guaiane, prenylated-germacrane, and 
prenylated-epi-elemane. A total of 58 diterpenes of Group 1, including 47 prenylated-guaiane diterpenes, have been isolated from Dictyota species by the end of 2017. Most of the compounds exhibit biological properties, such as cytotoxic [14], antitumor [15], antiviral [16], antifouling [17] and antioxidant activities [15]. Tables 1-3 summarize 58 diterpenes of Group 1 derived from the Dictyota species (see in Section 2.1).

\subsection{Prenylated-Guaiane Diterpenes}

Up to the end of 2017, a total of 47 prenylated-guaiane diterpenes had been reported, and nearly half of them were isolated from $D$. dichotoma. Some prenylated-guaiane diterpenes from Dictyota species contain a chlorine substituent.

A family of cytotoxic diterpenes, named dictyols A-D (1-4) and dictyol B acetate (5), were isolated from D. dichotoma var. implexa which was collected from the Tyrrhenian Sea [18]. Compound 3 showed moderate antifouling activity against the freshwater mollusk Limnoperna fortunei without any toxic effects [17]. Compound 3 displayed weak protection activity against DNA damage, low antioxidant activity for ABTS (2,2'-azino-bis-3-ethylbenzthiazoline-6-sulfonic acid) and erythrocytes hemolysis [15]. Compound 5 exhibited moderate cytotoxic activity against human embryonic kidney cell line (Hek-293), oral carcinoma cells (KB), epithelial carcinoma of the larynx (Hep-2), breast cancer cells (MCF-7), and cervix adenocarcinoma ( $\mathrm{SiHa}$ ) cell lines with $\mathrm{IC}_{50}$ values ranging from 19.6 to $59.2 \mu \mathrm{g} / \mathrm{mL}$. Compound 5 also showed weak antiproliferative activity against MCF-7 and SiHa cell lines with $\mathrm{IC}_{50}$ values of 38.3 and $34.4 \mu \mathrm{g} / \mathrm{mL}$, respectively [14]. Compound 5 showed significant inhibition against the cyanobacterium Oscillatoria perornata with an $\mathrm{IC}_{50}$ value of $2.23 \mu \mathrm{M}$ [19]. Additionally, 5 exhibited significant anti-herbivory activity against the crab Pachygrapsus transversus [20]. A novel diterpene, named dictyol-D-2 $\beta$-acetate (6), was isolated from D. dichotoma collected near Puerto Madryn [21]. Dictyol E (7) was isolated from D. dichotoma, collected from the Red Sea coast of Egypt [22], and from several species of Dictyota in the Mediterranean region [23]. Compound 7 showed weak antibacterial activity against the marine bacterial strains Pseudoalteromonas sp. (D41), Paracoccus sp. (4M6) and Polaribacter sp. (TC5) with $\mathrm{EC}_{50}$ values of 100,133, and $92 \mu \mathrm{M}$, respectively. Compound 7 also displayed a significant inhibitory effect on rat liver microsomal diacylglycerol acyltransferase with an $\mathrm{IC}_{50}$ value of $46.0 \mu \mathrm{M}$ [24]. Dictyol G acetate (8) was obtained from D. volubilis, collected from the reef flat of Geoffrey Bay, Magnetic Island, Australia [25], and also from D. binghamiae, collected from Barkley Sound, British Columbia [26]. Dictyol H (9) was reported from D. divaricata, collected from the Great Barrier Reef region of Northern Australia [27], and also from D. dentata from the south west coast of Barbados [28]. Compound 9 displayed moderate antitumor activity against KB9 cell line with an $\mathrm{IC}_{50}$ value of $22 \mu \mathrm{g} / \mathrm{mL}$ [28]. Dictyol I acetate (10) was isolated from D. dichotoma var. implexa from the Northern Adriatic Sea [18]. A chlorine-containing diterpene, dictyol J (11), was reported from D. dichotoma by bioassay-guided isolation. Compound $\mathbf{1 1}$ exhibited high (more than $95 \%$ ) algicidal activity against the red-tide phytoplankton Heterosigma akashiwo and Karenia mikimotoi at a dose of 10-20 $\mu \mathrm{g} / \mathrm{mL}$ [29]. Prenylated-guaiane diterpenes, pachydictyol A (12) and isopachydictyol A (13) were isolated from several species of Dictyota, such as D. menstrualis, D. caribaea, D. dichotoma var. Implexa, and D. volubilis $[14,15,17,18,20,30,31]$. Compounds $\mathbf{1 2}$ and $\mathbf{1 3}$ showed potent antithrombotic effect through inhibition of thrombin, displaying an inhibition of $50 \%$ at $0.68 \mathrm{mM}$ [30]. These compounds also displayed moderate to strong cytotoxicity against hepatoma (HepG2), fibroblast (WI-38), African green monkey kidney (VERO), and MCF-7 cell lines with $\mathrm{IC}_{50}$ values ranging from 22.4 to $40.2 \mu \mathrm{g} / \mathrm{mL}$ [15]. Compound 12 displayed a significant antifouling activity against the invading freshwater mussel Limnoperna fortunei at $4.7 \mu \mathrm{g} \mathrm{cm}{ }^{-2}$ [17]. Three new diterpenes, named cis-pachydictyol B (14), trans-pachydictyol B (15), and pachydictyol C (16), were isolated from D. dichotoma, collected from the Red Sea coast of Egypt. Compounds 14 and 16 exhibited weak cytotoxicity against 12 human tumor cell lines with a mean $\mathrm{IC}_{50}$ value $>30.0 \mu \mathrm{M}$. Compound $\mathbf{1 4}$ displayed a potent antimicrobial activity against the fungus Mucor miehei, and weak antifungal activity against Candida albicans and Pythium ultimum [22]. A new diterpene, named $8 \alpha, 11$-dihydroxypachydictyol A (17), was isolated from D. plectens [16] 
and from Dictyota sp., collected from Bang Saen Beach, Thailand [32]. Compound 17 displayed moderate antiviral activity against hemagglutinin-mediated viral entry with an inhibition rate of $56 \%$ at $30.0 \mu \mathrm{M}$ [16]. Additionally, this compound also showed strong cytotoxicity against National Cancer Institute human small cell lung carcinoma (NCI-H187 cells) with an $\mathrm{IC}_{50}$ value of $5.0 \mu \mathrm{g} / \mathrm{mL}$, and potent anti-malarial activity with an $\mathrm{IC}_{50}$ value of $3.22 \mu \mathrm{g} / \mathrm{mL}$ [32]. Another analog of pachydictyol A, 8 $\beta$-hydroxypachydictyol A (18), was reported from D. plectens [16], D. bartayresii [33] and D. dichotoma var. Implexa, collected from the Red Sea [15]. This compound displayed weak cytotoxicity against HepG2, WI-38 (fibroblast cells), VERO and MCF-7 cell lines with $\mathrm{IC}_{50}$ values of 81.2, 62.6, 72.3, and $68.2 \mu \mathrm{g} / \mathrm{mL}$, respectively [15]. Moreover, this compound was found to inhibit HIV-1 replication with an $\mathrm{IC}_{50}$ value of $26.1 \pm 1.7 \mu \mathrm{M}$ [16]. A new diterpene, named 3,4-epoxy-13-hydroxypachydictyol A (19), was obtained from $D$. dichotoma, collected in the Red Sea [34]. Three novel diterpenes, named acutilols A and B (20 and 21) and acutilol A acetate (22), were isolated from D. acutiloba, collected in Hawaii. Compounds 20-22 exhibited a significant feeding deterrent activity against both temperate and tropical herbivorous fishes as well as sea urchins [13,35]. Dictyoxide (23), isolated from Patagonian D. dichotoma, showed a potent antifouling activity against the invading freshwater mussel L. fortune at $4.7 \mu \mathrm{g} \mathrm{cm}^{-2}$ [17]. A prenylated-guaiane diterpene, named 2-hydroxydictyoxide (24), was isolated from $D$. divaricata from the Great Barrier Reef region of Northern Australia [27]. Two new diterpenes, dictyoxide A (25) and dictyotriol A diacetate (26), were identified from D. binghamiae, collected from Barkley Sound, British Columbia, while dictytriol (27) was isolated from a Japanese D. dichotoma [26]. Dictyone (28) and dictyone acetate (29) were isolated from $D$. dichotoma from the Red Sea coasts in Egypt [34]. Compound 28 and 29 showed moderate cytotoxicity against three proliferating mouse cell lines, a normal fibroblast line NIH3T3, and two virally transformed forms SSVNIH3T3 and KA3IT with $\mathrm{IC}_{50}$ values ranging from 5 to $35 \mu \mathrm{g} / \mathrm{mL}$ [36] (Figure 1).

Table 1. Bioactivities of prenylated-guaiane diterpenes (1-29) from the genus Dictyota.

\begin{tabular}{|c|c|c|c|c|}
\hline Structure Class & Metabolites & Sources & Activities & References \\
\hline \multirow{7}{*}{ Dictyols } & Dictyols A and B $(\mathbf{1}, \mathbf{2})$ & $\begin{array}{l}\text { D. dichotoma var. implexa, } \\
\text { Tyrrhenian sea }\end{array}$ & nd (not determined) & [18] \\
\hline & Dictyol C (3) & $\begin{array}{l}\text { D. divaricata, Great Barrier } \\
\text { Reef region } \\
\text { D. dentata, Boomers Beach } \\
\text { Barbados } \\
\text { D. dichotoma var. implexa, } \\
\text { Tyrrhenian sea } \\
\text { D. dichotoma, Patagonia }\end{array}$ & $\begin{array}{l}\text { Protection for DNA damage; } \\
\text { Antitumor activity; } \\
\text { Antioxidant activity; } \\
\text { Antifouling activity }\end{array}$ & {$[15,17,18,27,28]$} \\
\hline & Dictyol D (4) & $\begin{array}{l}\text { D. dichotoma var. implexa, } \\
\text { Tyrrhenian sea }\end{array}$ & nd & [18] \\
\hline & Dictyol B acetate (5) & $\begin{array}{l}\text { D. dichotoma var. Implexa, } \\
\text { Tyrrhenian sea } \\
\text { D. caribaea, } \\
\text { Dictyota ciliolata, Caribbean } \\
\text { coast, Yucatan peninsula }\end{array}$ & $\begin{array}{l}\text { Significant anti-herbivory } \\
\text { activity; } \\
\text { Selective antialgal activity; } \\
\text { Moderate cytotoxicity; } \\
\text { Antiproliferative activity }\end{array}$ & {$[14,18-20]$} \\
\hline & Dictyol G acetate (8) & $\begin{array}{l}\text { D. volubilis, Geoffrey Bay, } \\
\text { Australia } \\
\text { D. binghamiae, Barkley } \\
\text { Sound, British Columbia }\end{array}$ & nd & {$[25,26]$} \\
\hline & Dictyol H (9) & $\begin{array}{l}\text { D. divaricata, Great Barrier } \\
\text { Reef region } \\
\text { D. dentata, Boomers Beach }\end{array}$ & Moderate antitumor activity & {$[27,28]$} \\
\hline & Dictyol I acetate (10) & $\begin{array}{l}\text { D. dichotoma var. Implexa, } \\
\text { Northern Adriatic sea }\end{array}$ & nd & [18] \\
\hline
\end{tabular}


Table 1. Cont.

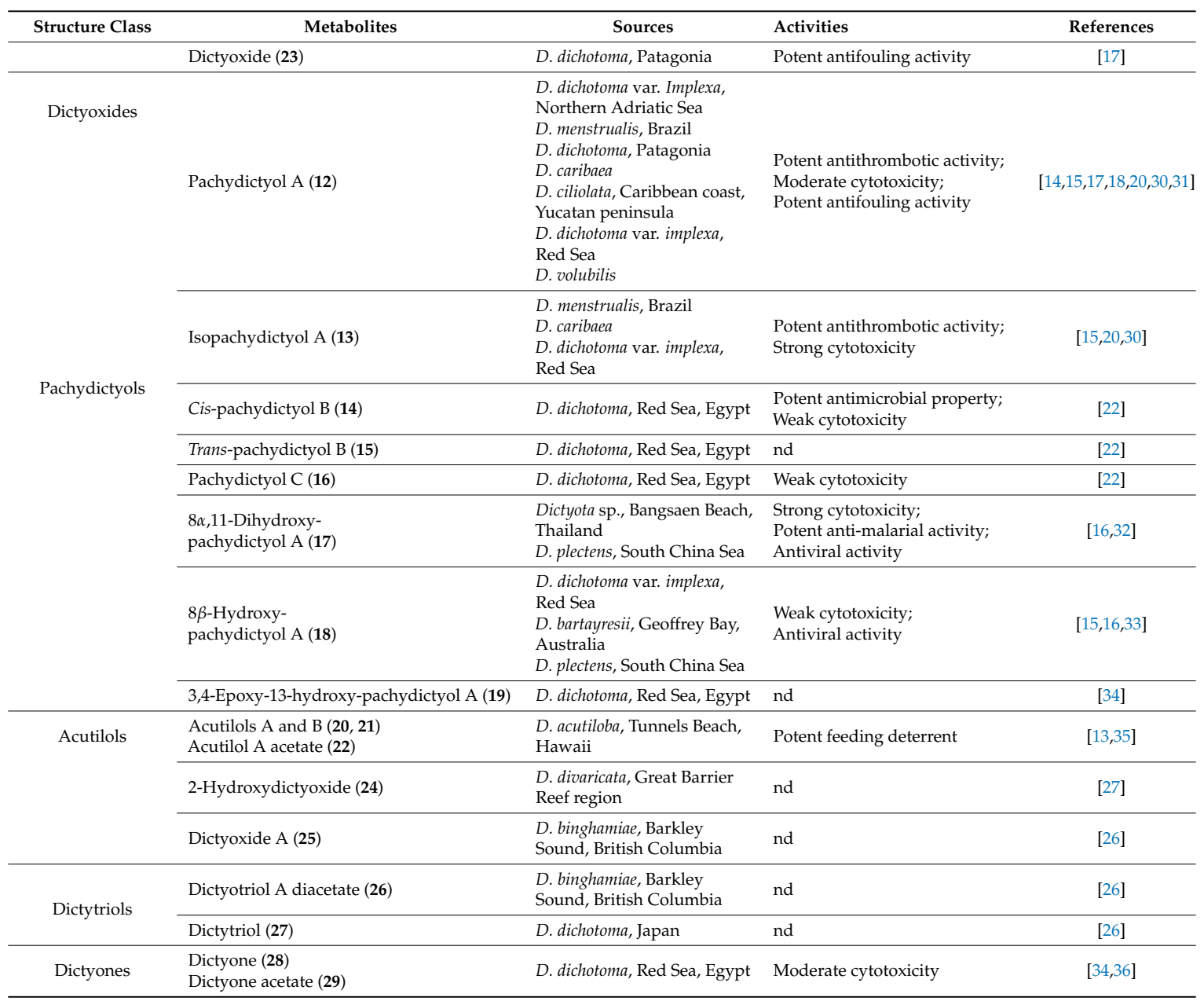

Table 2. Bioactivities of prenylated-guaiane diterpenes (30-47) from the genus Dictyota.

\begin{tabular}{|c|c|c|c|c|}
\hline Sources & Metabolites & Sources/Location & Activities & References \\
\hline \multirow{2}{*}{ D. volubilis } & $30-33$ & $\begin{array}{l}\text { Magnetic Island, Queensland, } \\
\text { Australia }\end{array}$ & nd & [25] \\
\hline & $34-41$ & & nd & [31] \\
\hline D. plectens & $\begin{array}{l}9 \alpha \text {-Hydroxydictyol (42) } \\
\text { Isodictyol E (43) }\end{array}$ & South China Sea & Antiviral activity & [16] \\
\hline \multirow{3}{*}{ D. dichotoma } & Dictyotadiol (44) & Patagonia & Weak antifouling activity & [17] \\
\hline & Dictyohydroperoxide (45) & Troitsa Bay, Russian Far East & Moderate cytotoxicity & [37] \\
\hline & Isopachydictyolal (46) & Saronicos gulf, Greece & Antiviral activity & {$[38]$} \\
\hline Genus Dictyota & 47 & Dictyota spp., Mediterranean Sea & nd & [23] \\
\hline
\end{tabular}

Table 3. Bioactivities of other diterpenes of Group 1 (48-58) from the genus Dictyota.

\begin{tabular}{ccccc}
\hline Structure Class & Metabolites & Sources & Activities & References \\
\hline & Hydroxydilophol (48) & D. masonii Isla Guadalupe, Pacific Mexico & nd & [39] \\
\cline { 2 - 5 } Prenylated-germacrane & Dilophol (49) & D. divaricata, Great Barrier Reef region & nd & [40] \\
\cline { 2 - 5 } & $\begin{array}{c}\text { Dictyota sp., Le Brusc Lagoon } \\
\text { D. divaricata, Great Barrier Reef region }\end{array}$ & nd & [40,41] \\
\cline { 2 - 5 } Prenylated-cadinane & $\begin{array}{c}3 \beta \text {-Acetoxydilophol (51) } \\
\text { Acetoxypachydiol (52) }\end{array}$ & D. plectens, South China Sea & Weak antiviral activity & [16] \\
\cline { 2 - 5 } & Dictyotins A-C (53-55) & D. dichotoma & nd & [42] \\
\hline Prenylated-epi-elemane & $\begin{array}{c}\text { Ent-erogorgiaene (56) } \\
\mathbf{5 7}\end{array}$ & D. dichotoma, Russian Far-east & [43] \\
\hline
\end{tabular}



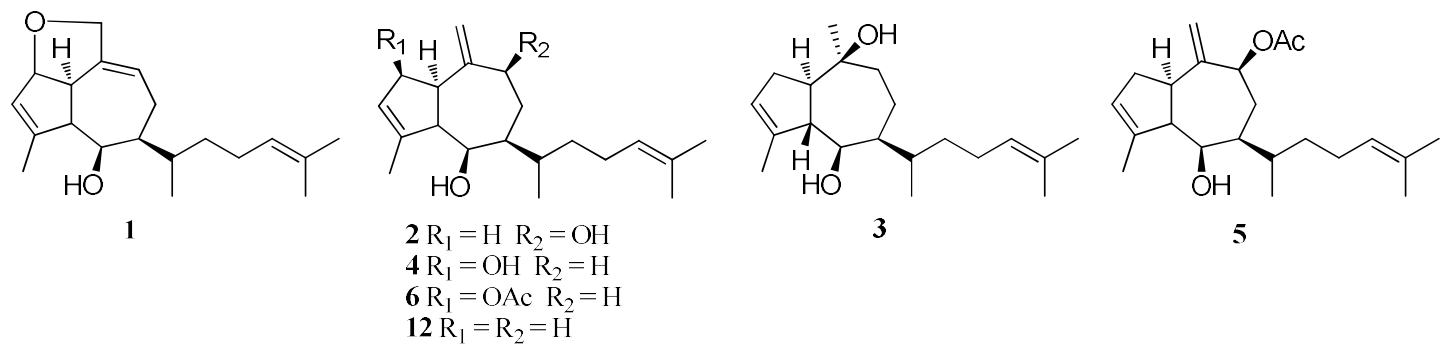

$4 \mathrm{R}_{1}=\mathrm{OH} \mathrm{R} \mathrm{R}_{2}=\mathrm{H}$

$12 \mathrm{R}_{1}=\mathrm{R}_{2}=\mathrm{H}$
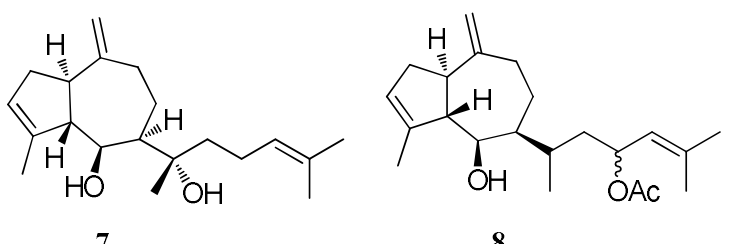

8
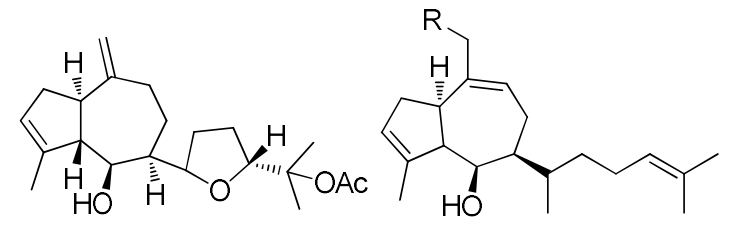

9

$10 \mathrm{R}=\mathrm{OAC}$

$13 \mathrm{R}=\mathrm{H}$

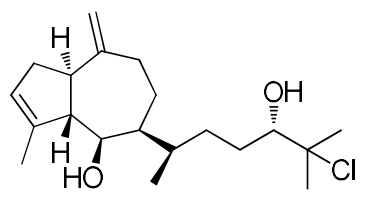

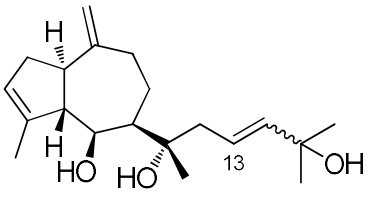

$14 Z-\triangle^{13}$

$15 E-\triangle^{13}$

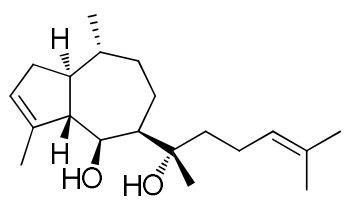

16

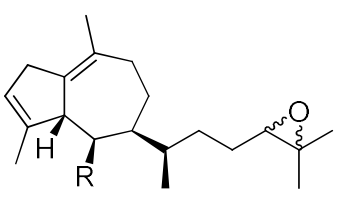

$20 \mathrm{R}=\mathrm{OH}$

$22 \mathrm{R}=\mathrm{OAc}$

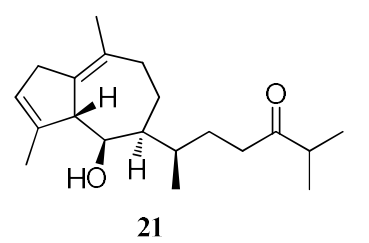

21

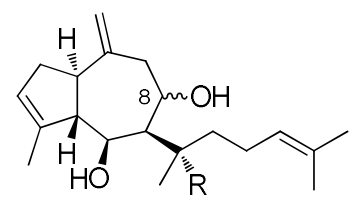

$17 \mathrm{R}=\mathrm{OH} 8 \alpha$

$18 \mathrm{R}=\mathrm{H} 8 \beta$

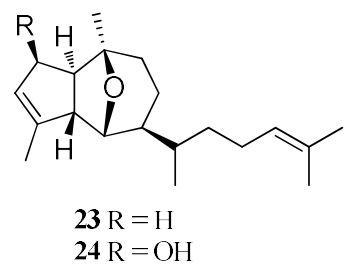<smiles>C=C1CCC2[C@@H](C)CCO[C@H]2C2C(C)=CC[C@H]12</smiles>

25

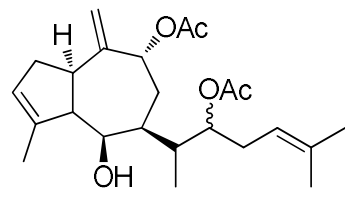

26

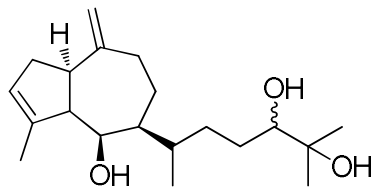

27

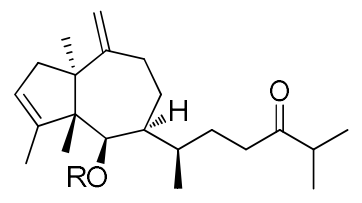

$28 \mathrm{R}=\mathrm{H}$ $29 \mathrm{R}=\mathrm{Ac}$

Figure 1. Chemical structures of 1-29.

Compounds 30-33 were isolated from D. volubilis which was collected from Magnetic Island, Queensland, Australia [25]. Compounds 34-41, which are highly oxidized prenylated-guaiane diterpenes, were reported from $D$. volubilis [31]. Two new diterpenes (42 and 43 ) were isolated from D. plectens which was collected from the South China Sea [16]. Dictyotadiol (44), isolated from Patagonian $D$. dichotoma, was found to display weak antifouling activity against the freshwater mollusk L. fortunei at $12 \mu \mathrm{g} \mathrm{cm}^{-2}$ [17]. Dictyohydroperoxide (45), a diterpene containing hydroperoxyl groups, was isolated from D. dichotoma, collected from the Troitsa Bay of Russian Far East. This compound was found to display a moderate cytotoxicity against HeLa, HL-60, and MDA-MB-231 human tumor cells and mouse epithelial cell line JB6 C141 with $\mathrm{IC}_{50}$ values of 71, 59, 201, and $68 \mu \mathrm{M}$, respectively [37]. A new diterpene, isopachydictyolal (46), was reported from $D$. dichotoma which was collected in the Saronicos Gulf in the Aegean Sea, Greece. This compound exhibited antiviral activity against Vero 
cells with a maximal non-toxic dose (MNTD) value of $10 \mu \mathrm{g} / \mathrm{mL}$ [38]. Compound 47 was obtained from the Mediterranean Dictyota spp. [23] (Figure 2).

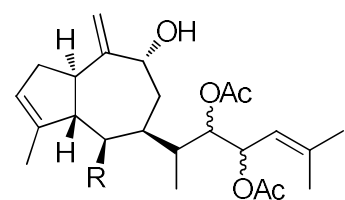

$30 \mathrm{R}=\mathrm{OAc}$

$31 \mathrm{R}=\mathrm{OH}$

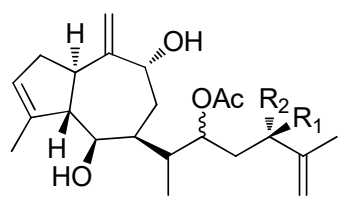

$37 \mathrm{R}_{1}=\mathrm{OH} \mathrm{R}_{2}=\mathrm{H}$

$38 \mathrm{R}_{1}=\mathrm{H} \mathrm{R}_{2}=\mathrm{OH}$<smiles>C=C1C(O)CC([C@](C)(O)CCC=C(C)C)C(O)C2C(C)=CC[C@H]12</smiles>

42<smiles>C=C1C(O)CC(C(C)C(C=CC(C)(C)O)OC(C)(C)O)C(O)[C@H]2CC=C(C)[C@H]12</smiles>

32<smiles>C=C1CC[C@H](C(C)CC(C=C(C)C)OC(C)=O)C(O)[C@@]2(C)C(=C)C=C[C@H]12</smiles>

39

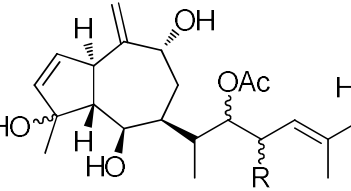

$33 \mathrm{R}=\mathrm{H}$

$35 \mathrm{R}=\mathrm{OAc}$

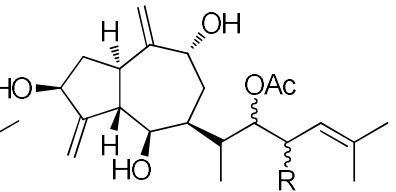

$34 \mathrm{R}=\mathrm{OAC}$

$36 \mathrm{R}=\mathrm{H}$

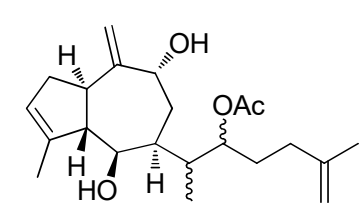

40

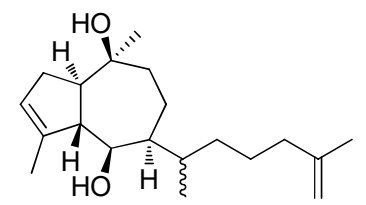

41

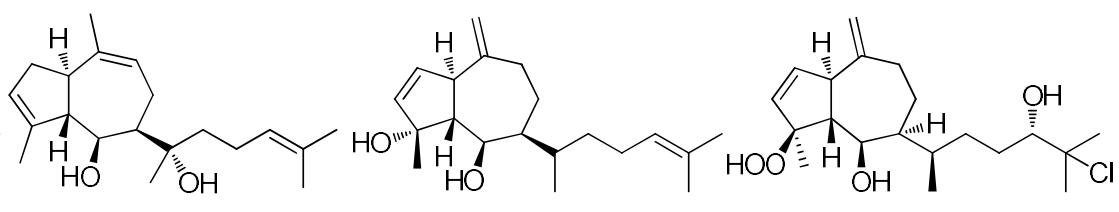

43

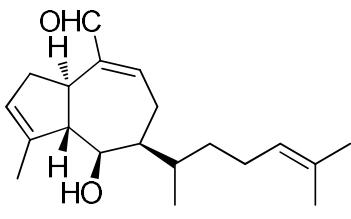

46

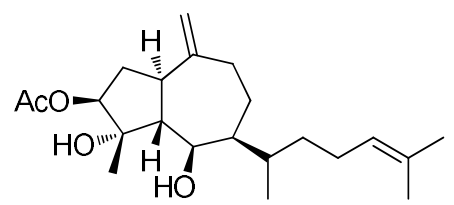

47

Figure 2. Chemical structures of 30-47.

\subsection{Other Diterpenes of Group 1}

Besides prenylated-guaiane diterpenes, other diterpene skeletons belonging to Group 1 have also been isolated from members of Dictyota (Figure 3). A germacrane diterpene, named hydroxydilophol (48), was isolated from D. masonii which was collected at Isla Guadalupe in the Pacific of Mexico [39]. Two germacrane diterpenes (49 and 50) were isolated from $D$. divaricata, collected from the Great Barrier Reef region of Northern Australia [40]. Moreover, $\mathbf{5 0}$ was also isolated from the Mediterranean Dictyota sp. [41]. Two germacrane diterpenes, (51 and 52) were obtained from D. plectens, collected from the South China Sea. These compounds showed weak antiviral activity against HA-mediated viral entry at $30.0 \mu \mathrm{M}$ [16]. Three cadinane diterpenes, named dictyotins A-C (53-55), were reported from D. dichotoma [42]. Two prenylated-cadinane diterpenes, 56 and 57, were identified from D. dichotoma, collected from the Russian Far East [43], while 58, a prenylated-epi-elemane diterpene, was isolated from D. volubilis [31]. 


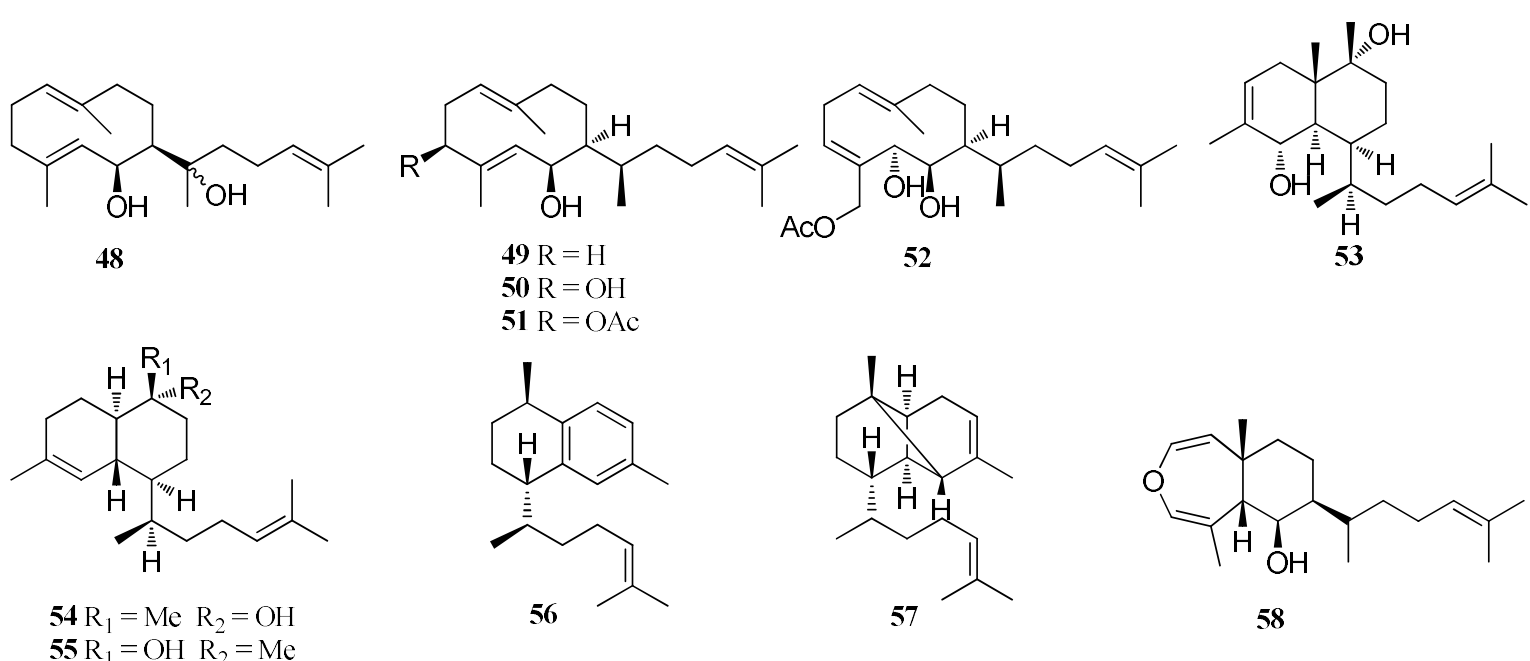

Figure 3. Chemical structures of $48-58$.

\section{Diterpenes of Group 1I}

Based on the revised biogenetic scheme widely cited, Group II consists of diterpenes derived by a first cyclization of the geranyl-geraniol precursor between C-1 and C-11 [1]. The diterpene skeletons of this group comprise the dolabellane, dolastane, secodolastane etc. A total of 120 diterpenes of Group II, including 69 dolabellane diterpenes, were isolated from Dictyota species by the end of 2017, most of which exhibit biological properties, such as antibiotic [44], cytotoxic [45], antiviral [46], antibacterial [47], and protection activities against DNA damage [15] in addition to other biological activities. Tables 4-6 summarize 120 diterpenes of Group II identified from Dictyota species (see at the end of this section).

\subsection{Dolabellane Diterpenes}

Dolabellane diterpenes bearing the 5,11-fused bicyclic skeleton constitute a large number of diterpenes with structural diversity, including specific hydroxylation, oxidation, epoxidation, and other reactions [48]. A total of 69 compounds have been isolated from the genus Dictyota, among which 25 have been found from $D$. dichotoma. Dolabellane diterpenes were originally isolated from the opistobmnch mollusc Dolabella californica in 1977 [48]. Later, they were isolated from other marine organisms, including sponges, sea whips, and brown algae of the genus Dictyota [49].

D. dichotoma is a chemically prolific member of the genus Dictyota since there are 25 structurally diverse dolabellane diterpenes from this alga (Figure 4). Nine dolabellane diterpenes, 59-67, were isolated from D. dichotoma, collected from Acicastello near Catania, Sicily, Italy [44]. Compound 67 showed strong cytotoxic activity against murine leukemia cells (P-388), human nasopharynx carcinoma (KB) and human non-small cell lung carcinoma (NSCLCN6-L16) cells with $\mathrm{ED}_{50}$ values of 6.5, 25.39, and $16.66-16.78 \mu \mathrm{g} / \mathrm{mL}$, respectively [50]. Fifteen novel dolabellanes, 68-82, were reported from D. dichotoma collected in Krusadai Island, Gulf of Mannar, India in 1983 [51]. In addition, 79-82 were isolated from D. bartayresiana, collected on the coast of Hare Island, Gulf of Mannar, India in 1985 [52]. A cytotoxic diterpene, named dolabellatrienol (83), was isolated from the Red Sea D. dichotoma var. implexa, and it showed moderate in vitro cytotoxicity against four human tumor cell lines, HepG2, WI-38, VERO, and MCF-7, with $\mathrm{IC}_{50}$ values of $102.3,100.6,120.6$, and $150.5 \mu \mathrm{g} / \mathrm{mL}$, respectively [15].

Besides $D$. dichotoma, other algae of this genus are also rich producers of bioactive dolabellane diterpenes (Figure 5). Fifteen compounds 84-98 were isolated from D. pardarlis f. pseudohamata from Magnetic Island [53-55]. Compounds 98-102 were also reported from D. bartayresiana, collected from Hare Island in the Gulf of Mannar of the Indian Ocean [52]. Three dolabellane diterpenes, 103-105, were isolated from D. pfaffii. Three antiviral diterpenes, named dolabelladienols A-C 
(106-108), were found from the same species, collected from Atol das Rocas, Northeast Brazil [46]. Compound 103 showed potent anti-HIV-1 effect ranging from $60 \%$ to $90 \%$ in peripheral blood cells (PBMC) and macrophages infected with the human immunodeficiency virus (HIV) from $60 \%$ to $90 \%$, respectively [56]. This compound also exhibited moderate inhibition against herpes virus at a concentration of $50 \mu \mathrm{M}$, and it was found to be moderately active against HIV-1 reverse transcriptase activity at a concentration of $40 \mu \mathrm{M}$ [57]. Moreover, 103 also displayed significant antimalarial activity against Leishmania amazonensis with an $\mathrm{IC}_{50}$ value of $44 \mu \mathrm{M}$ [58]. Compound 104, an antifeedant against the sea urchin and generalist fishes [13], exhibited strong anti-HSV-1 activity with a $C_{50}$ value of $185 \pm 5 \mu \mathrm{M}$ [57]. Compounds 106 and 107 exhibited strong anti-HIV-1 activity with $\mathrm{IC}_{50}$ values of 2.9 and $4.1 \mu \mathrm{M}$, respectively [46]. Compound 109 was isolated from D. pfaffii which was collected from Atol das Rocas in Northeast Brazil, and it displayed strong anti-HSV-1 activity, reaching an inhibition of $87 \%$ at a concentrate of $50 \mu \mathrm{M}$ [57]. Four antiviral diterpenes, 110-113, have been extracted from D. plectens which was collected from the South China Sea. These compounds showed specific inhibition against HA-mediated viral entry with an inhibition rate of $62 \%$ at $30.0 \mu \mathrm{M}$ [16].

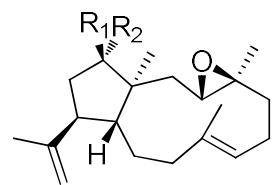

$59 \mathrm{R}_{1}=\mathrm{OH} \mathrm{R}_{2}=\mathrm{H}$ $60 \mathrm{R}_{1}=\mathrm{R}_{2}=\mathrm{H}$

$67 \stackrel{{ }^{\prime \prime \prime \prime \prime} R_{2}}{R_{2}}==0$<smiles></smiles>

$64 \mathrm{R}=\mathrm{H}$

$65 \mathrm{R}=\mathrm{OA}$

$66 \mathrm{R}=\mathrm{OH}$<smiles>C/C1=C/CC[C@]2(C)/C=C(/C)C(=O)CC3[C@@](O)(C(C)C)CC[C@]3(C)C[C@@H](C1)O2</smiles>

72

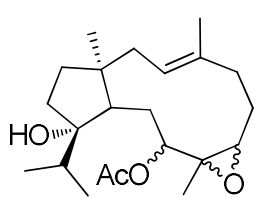

78

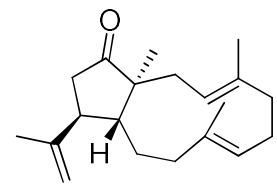

61

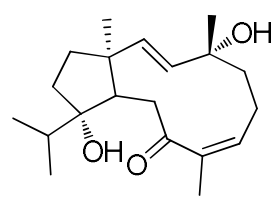

68<smiles>CC1C=CCC(C)(O)C=C[C@]2(C)CCC(O)C1CC2=O</smiles>

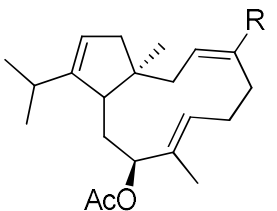

$79 \mathrm{R}=\mathrm{CHO}$ $80 \mathrm{R}=\mathrm{COOH}$

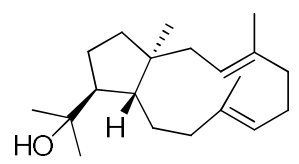

62

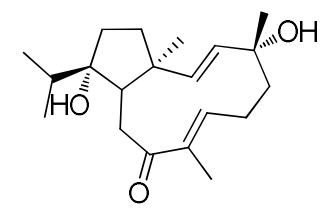

69<smiles>C/C1=C\C[C@]2(C)CC[C@](O)(C(C)C)C2CC(=O)[C@H](C)/C=C\C1</smiles>

$758 R$

$768 S$<smiles>C/C1=C/CC/C(C)=C/C[C@@](C)(CCC2CC2CC(=O)[C@]2(O)CC[C@@]2(C)C(C)C)C1</smiles>

81

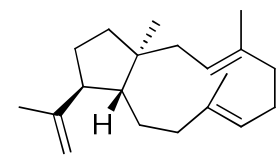

63

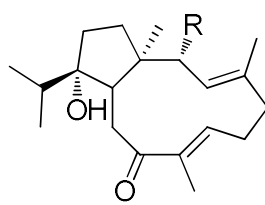

$70 \mathrm{R}=\mathrm{H}$

$71 \mathrm{R}=\mathrm{OAC}$<smiles>C/C1=C\C[C@]2(C)CC[C@](O)(C(C)C)C2CC(=O)[C@]2(C)O[C@H]2CC1</smiles>

77

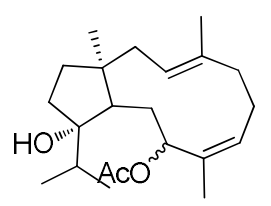

82<smiles>C/C=C\CC1=C(C(C)C)CCC1(C)C/C=C/C(C)CC(C)O</smiles>

83

Figure 4. Chemical structures of 59-83. 


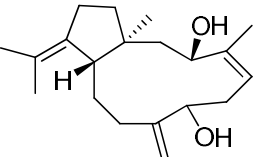

84<smiles>CC(=O)OC1C=C(C)/C(=C\CC2(C)CCC3(O)C(C)OC(C)CC23)CC1</smiles>

88

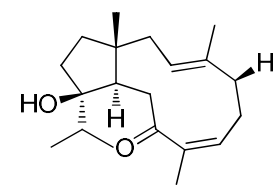

93

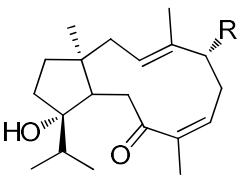

$101 \mathrm{R}=\mathrm{OAc}$ $102 \mathrm{R}=\mathrm{OH}$<smiles>C/C=C\C(C)=C/C(OC(C)=O)C1(C)CCC(O)(C(C)C)[C@H]1CC(=O)/C(C)=C/C</smiles>

110

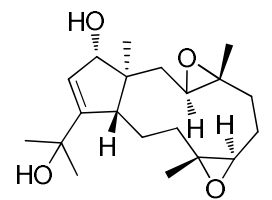

85

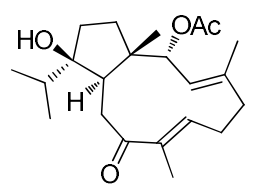

89

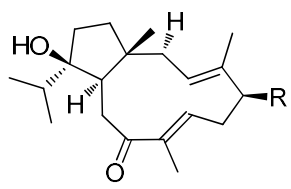

$94 \mathrm{R}=\mathrm{H}$ $95 \mathrm{R}=\mathrm{OAC}$

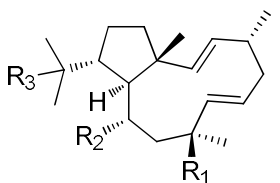

$103 \mathrm{R}_{1}=\mathrm{OH} \mathrm{R}_{2}=\mathrm{OH} \mathrm{R} \mathrm{R}_{3}=\mathrm{OH}$ $104 \mathrm{R}_{1}=\mathrm{OH} \mathrm{R} \mathrm{R}_{2}=\mathrm{OAc} \mathrm{R} \mathrm{R}_{3}=\mathrm{OAc}$ $105 \mathrm{R}_{1}=\mathrm{OH} \mathrm{R} \mathrm{R}_{2}=\mathrm{OAc} \mathrm{R}_{3}=\mathrm{OH}$ $109 \mathrm{R}_{1}=\mathrm{OAc} \mathrm{R}_{2}=\mathrm{OH} \mathrm{R}=\mathrm{OH}$

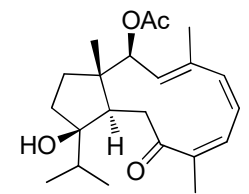

111

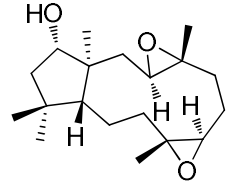

86

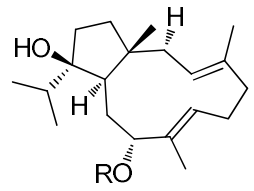

$90 \mathrm{R}=\mathrm{H}$

$91 \mathrm{R}=\mathrm{Ac}$

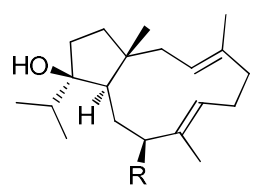

$96 \mathrm{R}=\mathrm{OH}$

$97 \mathrm{R}=\mathrm{OAc}$

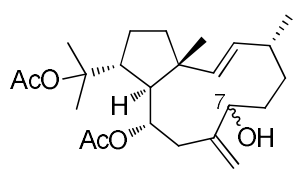

$1067 S$

$1077 R$

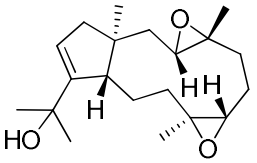

87

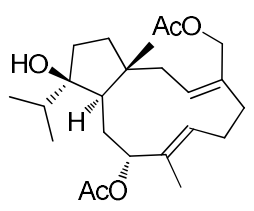

92

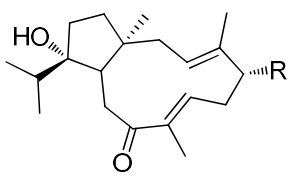

$98 \mathrm{R}=\mathrm{H}$

$99 \mathrm{R}=\mathrm{OAc}$

$100 \mathrm{R}=\mathrm{OH}$

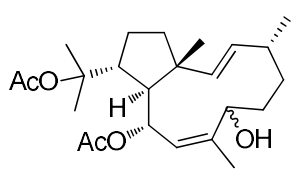

108

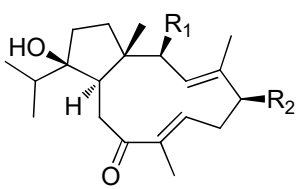

$112 \mathrm{R}_{1}=\mathrm{H} \mathrm{R}_{2}=\mathrm{OAc}$

Figure 5. Chemical structures of 84-113.

Besides the above-mentioned algae, other member of the genus Dictyota are also producers of bioactive dolabellane diterpenes (Figure 6). Compound $\mathbf{1 1 4}$ was isolated from $D$. divaricata collected from the Great Barrier Reef region of Northern Australia [40]. Compound 115 was isolated from D. volubilis [31]. On the other hand, 116-120 were isolated from Dictyota sp., collected near Portopalo. Compound 116 displayed significant in vitro cytotoxicity against KB cells [45]. Three antifouling compounds 121-123, were obtained during an investigation of a Mediterranean Dictyota sp. Compound 122 showed moderate antifouling activity against marine bacterial biofilm-forming bacteria D41 with an $\mathrm{EC}_{50}$ value of $110 \mu \mathrm{M}$, while compound 123 was weakly active with an $\mathrm{EC}_{50}$ value of 250 $\mu \mathrm{M}$ [41]. Four antifouling compounds 124-127 were isolated from Dictyota spp. collected from the Mediterranean coasts (France and Algeria) [23]. Both compounds 126 and 127 displayed weak anti-adhesion activity against D41 with an $\mathrm{EC}_{50}$ more than $100 \mu \mathrm{M}$. These compounds showed weak antibacterial activity against macrolide-resistant variant RN4220 with MIC values of 128 and 64 $\mu \mathrm{g} / \mathrm{mL}$, respectively [59]. Moreover, compound 127 exhibited selective inhibitory activity against the cyanobacterium Oscillatoria perornata with an $\mathrm{IC}_{50}$ value of $23.4 \mu \mathrm{M}$ [19]. 


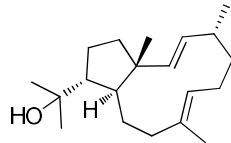

114

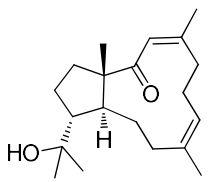

121

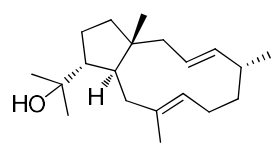

115

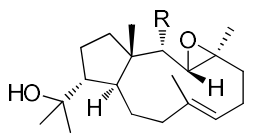
$122 \mathrm{R}=\mathrm{OH}$
$123 \mathrm{R}=\mathrm{H}$ $123 \mathrm{R}=\mathrm{H}$

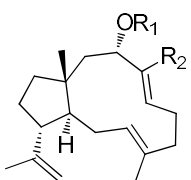

$116 \mathrm{R}_{1}=\mathrm{Ac} \mathrm{R}_{2}=\mathrm{CH}_{2} \mathrm{OH}$ $117 \mathrm{R}_{1}=\mathrm{H} \mathrm{R}_{2}=\mathrm{CH}_{2} \mathrm{OH}$ $118 \mathrm{R}_{1}=\mathrm{Ac} \mathrm{R}_{2}=\mathrm{CHO}$ $119 \mathrm{R}_{1}=\mathrm{H} \mathrm{R}_{2}=\mathrm{CH}_{2} \mathrm{OAC}$

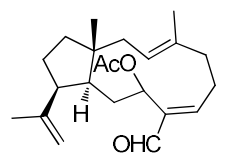

124

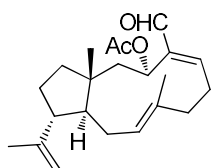

120

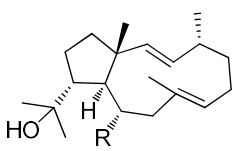

$125 \mathrm{R}=\mathrm{OH}$ $127 \mathrm{R}=\mathrm{OAC}$<smiles>C=C(C)[C@H]1CC(=O)[C@@]2(C)C[C@]3(C)O[C@]3(C)CCC=C(C)CC[C@@H]12</smiles>

126

Figure 6. Chemical structures of 114-127.

\subsection{Dolastane Diterpenes}

Dolastane diterpenes containing the 5,7,6-tricyclic skeleton are another class of bioactive constituents of brown algal species of the genus Dictyota [60]. At present, a total of 38 dolastane diterpenes have been obtained from Dictyota species.

Compound 128 was isolated from D. dichotoma, collected from the coast of the Indian Ocean [51], and also from D. bartayresiana, collected in the Gulf of Mannar of the Indian Ocean [52] while $\mathbf{1 2 9}$ was isolated from D. cervicornis [61] and D. dichotoma [62]. Two dolastane diterpenes, dichototetraol (130) and dichotopentaol (131), were isolated from D. dichotoma, collected from the Karachi Coast of the Arabian Sea [62]. Two diterpenes, named dichotenone A (132) and dichotenone B (133), were reported from the marine alga $D$. dichotoma [47], while amijiol (134) was isolated from $D$. indica, collected from Bulegi near the Karachi Coast of the Arabian Sea [63]. Compound 134 showed moderate antitumor activity [15]. Extensive efforts to discover bioactive natural products from the Red Sea D. dichotoma var. Implexa resulted in the isolation of three cytotoxic diterpenoids, amijiol (134), amijiol acetate (135), and amijiol-7,10-diacetate (136). Compound 135 exhibited strong antitumor activity against HepG2, WI-38, VERO, and MCF-7 with IC 50 values of $25.1,14.2,20.5$, and $21.2 \mu \mathrm{g} / \mathrm{mL}$, while 136 gave $\mathrm{IC}_{50}$ values of 47.0,16.2, 21.4 and $30.5 \mu \mathrm{g} / \mathrm{mL}$, respectively. Moreover, both 135 and 136 displayed potent anti-oxidative activity [15] (Figure 7).
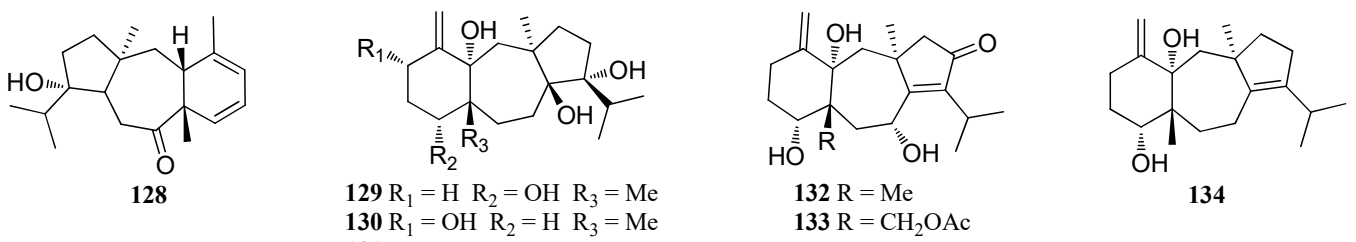

$131 \mathrm{R}_{1}=\mathrm{H} \mathrm{R}_{2}=\mathrm{OH} \mathrm{R} \mathrm{R}_{3}=\mathrm{CH}_{2} \mathrm{OH}$

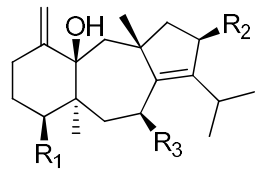

$135 \mathrm{R}_{1}=\mathrm{OAc} \mathrm{R}_{2}=\mathrm{H} \mathrm{R}_{3}=\mathrm{H}$

$136 \mathrm{R}_{1}=\mathrm{OH} \mathrm{R} \mathrm{R}_{2}=\mathrm{OAc} \mathrm{R}_{3}=\mathrm{OAc}$

Figure 7. Chemical structures of 128-136. 
A bioactive diterpene 137 was isolated from a Brazilian D. cervicornis [64]. This compound showed a strong antimalarial activity against promastigote, axenic amastigote and intracellular amastigote forms of Leishmania amazonensis with $\mathrm{IC}_{50}$ values of 2.0, 12.0, and $4.0 \mu \mathrm{g} / \mathrm{mL}$, respectively [65], in addition to antifouling effect [66] and inhibitory activity against the mammalian $\mathrm{Na}^{+} \mathrm{K}^{+}$-ATPase [64]. Compounds 138-140 were obtained from D. cervicornis, collected from Baia da Ribeira, Brazil [61]. Compound 141, was isolated from a Brazilian D. cervicornis [64] and was found to inhibit strong antifeedant activity with a herbivory inhibitory effect (HIE) value of 70\% [67] as well as antifouling activity against the mussel Perna perna [66]. Moreover, this compound also displayed significant inhibitory effect on HIV-1 replication with an $\mathrm{EC}_{50}$ value of $0.3 \mu \mathrm{M}$ [68].

Four dolastane diterpenes, 142-145, were isolated from $D$. divaricata, collected from the Virgin Islands [69]. Examination of the organic extract of D. indica, collected from Bulegi near the Karachi Coast of the Arabian Sea provided three diterpenes, dictinol (146), dictindiol (147), and dictintriol (148) [63]. Compounds 149-151 were reported from D. bartayresiana, collected in the Hare Island of the Gulf of Mannar of the Indian Ocean [52]. Three dolastane diterpenes, named isoamijiol (152), 14-deoxyamijiol (153), and amijidictyol (154), were isolated from $D$. linearis [70] and a total synthesis of compound 152 was accomplished [71]. Compounds 155-157 were isolated from D. plectens, collected from the South China Sea and were found to exhibit a weak anti-inflammatory activity against lipopolysaccharide (LPS)-induced nitric oxide (NO) production at $10.0 \mu \mathrm{M}$ [16] (Figure 8).

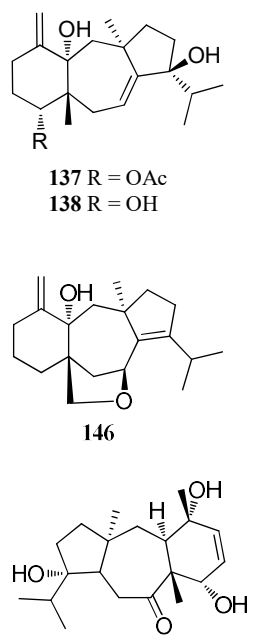

151

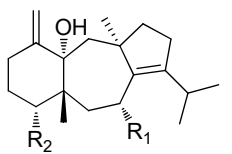

$139 \mathrm{R}_{1}=\mathrm{OAc} \mathrm{R}_{2}=\mathrm{OH}$ $140 \mathrm{R}_{1}=\mathrm{OH} \mathrm{R} \mathrm{R}_{2}=\mathrm{OAc}$ $141 \mathrm{R}_{1}=\mathrm{OAc} \mathrm{R}_{2}=\mathrm{OAc}$
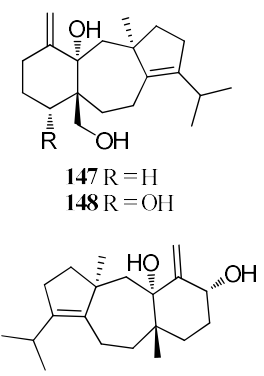

152

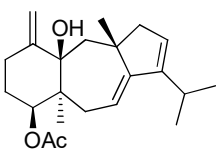

142

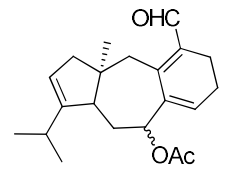

149

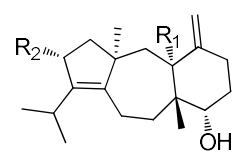

$153 \mathrm{R}_{1}=\mathrm{H} \mathrm{R}_{2}=\mathrm{H}$ $153 R_{1}=H R_{2}=H$
$154 R_{1}=O H R_{2}=O A C$ 1<smiles>C=C1CC[C@@H](O)[C@@]2(O)C[C@H](OC(C)=O)C3=C1C(C)C[C@]3(C)O2</smiles>

157

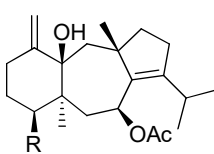

$143 \mathrm{R}=\mathrm{OH}$ $144 \mathrm{R}=\mathrm{OAc}$ $145 \mathrm{R}=\mathrm{H}$

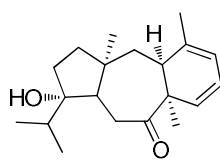

150

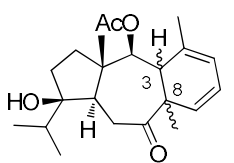

$1553 \alpha 8 \alpha$ $1563 \beta 8 \beta$

Figure 8. Chemical structures of 137-157.

Extracts of the mixed collections of two brown algae $D$. linearis and $D$. divaricata, from the Honduras Bay Islands, afforded seven dolastane diterpenes 137, 138, and 158-162. Compound 161 displayed a strong reversible inhibitory action of histamine on the guinea pig ileum at a concentration of $16 \mu \mathrm{g} / \mathrm{mL}$. Compound 162 showed moderate decrease in the twitch height of rat hemidiaphragm preparation at a concentration of $16 \mu \mathrm{g} / \mathrm{mL}$. Moreover, 162 displayed weak inhibition of cell division using an urchin egg assay [60]. Compound 163 was isolated from D. furcellata, collected from Cape Peron in Western Australia [72]. Two dolostane diterpenes 164 and 165, were isolated from Dictyota sp. from the Canary Islands [73] (Figure 9). 


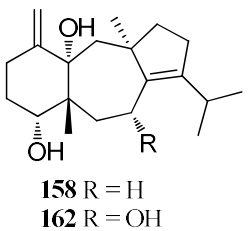

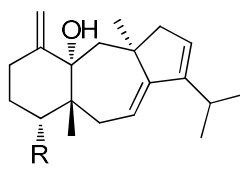

$159 \mathrm{R}=\mathrm{H}$ $161 \mathrm{R}=\mathrm{OAC}$ $164 \mathrm{R}=\mathrm{OH}$<smiles>C=C1CC[C@@H](O)[C@]2(C)CC=C3C(=CC[C@@]3(C)C(C)C)[C@]1(C)C2</smiles>

165

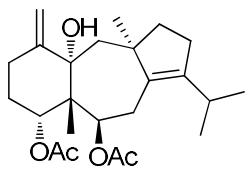

160

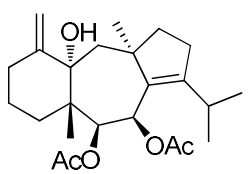

163

Figure 9. Chemical structures of 158-165.

\subsection{Secodolastane Diterpenes}

Secodolastane diterpenes are a class of compounds derived by decyclization of the dolastane skeleton between C-8 and C-9 [74]. A total of 12 secodolastane diterpenes were found in D. indica, D. cervicornis, or D. dichotoma (Figure 10).

Six secodolastane diterpenes, named linearol (166), isolinearol (167), linearol acetate (168), isolinearol acetate (169), cervicol (170), and cervicol acetate (171), were isolated from D. cervicornis, collected from Baia da Ribeira, Brazil [74]. The extracts of $D$. indica of the Arabian Sea furnished linearol (166), isolinearol (167), indicol (172), and indicarol acetate (173) [75]. Four secodolastane diterpenes, named dichotenols B and C (174 and 175), dichotone (176), and dichotodione (177), were isolated from D. dichotoma. Both $\mathbf{1 7 4}$ and $\mathbf{1 7 6}$ exhibited significant antibacterial and antifungal activities [47].

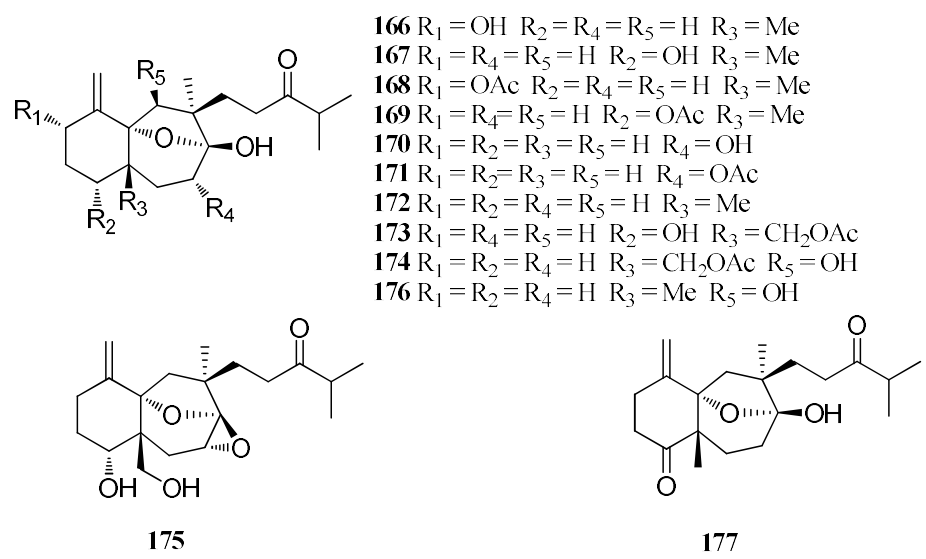

Figure 10. Chemical structures of 166-177.

\subsection{Dictyoxetane Diterpenes}

A dictyoxetane diterpene $\mathbf{1 7 8}$ was isolated from $D$. dichotoma, collected from the coast of the Indian Ocean [51] (Figure 11).

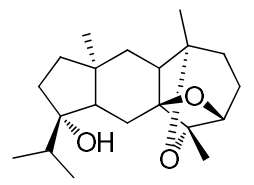

178

Figure 11. Chemical structure of 178. 
Table 4. Bioactivities of dolabellane diterpenes (59-127) from the genus Dictyota.

\begin{tabular}{|c|c|c|c|c|}
\hline Sources & Metabolites & Sources/Location & Activities & References \\
\hline \multirow{4}{*}{ D. dichotoma } & $59-66$ & Acicastello, Italy & Antibiotic property & [44] \\
\hline & 67 & Acicastello, Italy & Strong cytotoxicity & {$[44,50]$} \\
\hline & $68-82$ & Indian Ocean & nd & [51] \\
\hline & Dolabellatrienol (83) & D. dichotoma var. Implexa, Red Sea & Moderate cytotoxicity & [15] \\
\hline $\begin{array}{l}\text { D. pardarlis } \mathrm{f} . \\
\text { pseudohamata }\end{array}$ & $84-98$ & Magnetic Island & nd & [53-55] \\
\hline D. bartayresiana & $\begin{array}{c}79-82 \\
98-102 \\
\end{array}$ & Hare Island, Indian Ocean & nd & [52] \\
\hline \multirow{6}{*}{ D. pfaffii } & 103 & Atol das Rocas, Northeast Brazil & $\begin{array}{l}\text { Potent antiviral activity; } \\
\text { Significant antimalarial activity }\end{array}$ & {$[46,57,58]$} \\
\hline & 104 & Atol das Rocas, Northeast Brazil & $\begin{array}{l}\text { Antifeedant activity; } \\
\text { Antiviral activity }\end{array}$ & {$[13,46,57]$} \\
\hline & 105 & Atol das Rocas, Northeast Brazil & nd & [46] \\
\hline & Dolabelladienols A - B $(\mathbf{1 0 6}, \mathbf{1 0 7})$ & Atol das Rocas, Northeast Brazil & Strong antiviral activity & [46] \\
\hline & Dolabelladienol C (108) & Atol das Rocas, Northeast Brazil & nd & [46] \\
\hline & 109 & Atol das Rocas, Northeast Brazil & Strong anti-HSV-1 activity & [57] \\
\hline D. plectens & $110-113$ & South China Sea & Specific antiviral activity & [16] \\
\hline \multirow{9}{*}{ Genus Dictyota } & 103 & D. friabilis, Atol das Rocas reef & Potent anti-HIV-1 activity & [56] \\
\hline & 114 & D. divaricata, Great Barrier Reef region & nd & [40] \\
\hline & 115 & D. volubilis & nd & [31] \\
\hline & 116 & Dictyota sp., near Portopalo & Significant cytotoxicity & [45] \\
\hline & $117-120$ & Dictyota sp., near Portopalo & nd & [45] \\
\hline & $121-123$ & Dictyota sp., Le Brusc Lagoon & Antifouling activity & [41] \\
\hline & 124,125 & $\begin{array}{l}\text { Dictyota spp., Mediterranean coasts, } \\
\text { Frence and Algeria }\end{array}$ & nd & [23] \\
\hline & 126 & $\begin{array}{l}\text { Dictyota spp., Mediterranean coasts, } \\
\text { Frence and Algeria }\end{array}$ & $\begin{array}{l}\text { Anti-adhesion activity; } \\
\text { Antibacterial activity }\end{array}$ & {$[23,59]$} \\
\hline & 127 & $\begin{array}{l}\text { Dictyota spp., Mediterranean coasts, } \\
\text { Frence and Algeria } \\
\text { D. menstrualis, Discovery Bay, Jamaica }\end{array}$ & $\begin{array}{l}\text { Anti-adhesion activity; } \\
\text { Antibacterial activity; } \\
\text { Anti-algal activity }\end{array}$ & {$[19,23,41,59]$} \\
\hline
\end{tabular}

Table 5. Bioactivities of dolastane diterpenes (128-165) from the genus Dictyota.

\begin{tabular}{|c|c|c|c|c|}
\hline Sources & Metabolites & Sources/Location & Activities & References \\
\hline \multirow{4}{*}{ D. dichotoma } & 128 & Indian Ocean & nd & [51] \\
\hline & $\begin{array}{c}129 \\
\text { Dichototeraol (130) } \\
\text { Dichotopentaol (131) }\end{array}$ & Karachi coast, Arabian Sea & nd & [62] \\
\hline & Dichotenones A and B $(\mathbf{1 3 2}, \mathbf{1 3 3})$ & & nd & [47] \\
\hline & $\begin{array}{c}\text { Amijiol (134) } \\
\text { Amijiol acetate (135) } \\
\mathbf{1 3 6}\end{array}$ & D. dichotoma var. Implexa, Red Sea & $\begin{array}{l}\text { Antitumor activity; } \\
\text { Anti-oxidative activity }\end{array}$ & [15] \\
\hline \multirow{3}{*}{ D. cervicornis } & 137 & Brazil & $\begin{array}{l}\text { Strong antimalarial activity; } \\
\text { Antifouling activity; } \\
\text { Enzyme inhibitory activity }\end{array}$ & [64-66] \\
\hline & $\begin{array}{c}129 \\
138-140\end{array}$ & Baia da Ribeira, Brazil & nd & [61] \\
\hline & 141 & Rio de Janeiro, Brazil & $\begin{array}{l}\text { Strong antifeedant activity; } \\
\text { Antifouling activity; } \\
\text { Antiviral activity }\end{array}$ & {$[64,66-68]$} \\
\hline D. divaricata & $142-145$ & Virgin Islands & nd & [69] \\
\hline D. indica & $\begin{array}{c}134 \\
\text { Dictinol (146) } \\
\text { Dictindiol (147) } \\
\text { Dictintriol (148) }\end{array}$ & Bulegi, Arabian Sea & nd & [63] \\
\hline D. bartayresiana & $\begin{array}{c}128 \\
149-151\end{array}$ & Hare Island, Indian Ocean & nd & {$[52]$} \\
\hline
\end{tabular}


Table 5. Cont.

\begin{tabular}{|c|c|c|c|c|}
\hline Sources & Metabolites & Sources/Location & Activities & References \\
\hline D. linearis & $\begin{array}{l}\text { Isoamijiol (152) } \\
\text { 14-Deoxyamijiol (153) } \\
\text { Amijidictyol (154) }\end{array}$ & & nd & {$[70,71]$} \\
\hline D. plectens & $155-157$ & South China Sea & Weak anti-inflammatory activity & [16] \\
\hline \multirow{5}{*}{ Genus Dictyota } & $\begin{array}{l}137-138 \\
158-160\end{array}$ & $\begin{array}{l}\text { Mixed collections of } D \text {. linearis and } D \text {. } \\
\text { divaricata, Honduras Bay Islands }\end{array}$ & nd & [60] \\
\hline & 161 & $\begin{array}{l}\text { Mixed collections of } D \text {. linearis and } D \text {. } \\
\text { divaricata, Honduras Bay Islands }\end{array}$ & $\begin{array}{l}\text { Strong reversible inhibitory } \\
\text { activity }\end{array}$ & [60] \\
\hline & 162 & $\begin{array}{l}\text { Mixed collections of } D \text {. linearis and } D \text {. } \\
\text { divaricata, Honduras Bay Islands }\end{array}$ & $\begin{array}{l}\text { Moderate decrease in the twitch } \\
\text { height; } \\
\text { Weak inhibition of cell division }\end{array}$ & [60] \\
\hline & 163 & D. furcellata, Cape Peron & nd & [72] \\
\hline & 164,165 & Dictyota sp., Canary Islands & nd & [73] \\
\hline
\end{tabular}

Table 6. Bioactivities of secodolastane diterpenes (166-177) from the genus Dictyota.

\begin{tabular}{|c|c|c|c|c|}
\hline Structure Class & Metabolites & Sources & Activities & References \\
\hline \multirow{2}{*}{ Linearols } & $\begin{array}{c}\text { Linearol (166) } \\
\text { Isolinearol (167) }\end{array}$ & $\begin{array}{c}\text { D. indica Arabian Sea } \\
\text { D. cervicornis Baia da Ribeira Brazil }\end{array}$ & nd & {$[74,75]$} \\
\hline & $\begin{array}{l}\text { Linearol acetate }(\mathbf{1 6 8}) \\
\text { Isolinearol acetate }(\mathbf{1 6 9})\end{array}$ & D. cervicornis Baia da Ribeira Brazil & nd & [74] \\
\hline Cervicols & $\begin{array}{c}\text { Cervicol (170) } \\
\text { Cervicol acetate (171) }\end{array}$ & D. cervicornis Baia da Ribeira Brazil & nd & [74] \\
\hline Indicols & $\begin{array}{c}\text { Indicol (172) } \\
\text { Indicarol acetate (173) }\end{array}$ & D. indica Arabian Sea & nd & [75] \\
\hline \multirow[t]{2}{*}{ Dichotenols } & Dichotenol B (174) & D. dichotoma & $\begin{array}{l}\text { Significant antibacterial and } \\
\text { anti-fungal activity }\end{array}$ & [47] \\
\hline & Dichotenol C (175) & D. dichotoma & nd & [47] \\
\hline \multirow{2}{*}{ Others } & Dichotone (176) & D. dichotoma & $\begin{array}{l}\text { Significant antibacterial and } \\
\text { anti-fungal activity }\end{array}$ & [47] \\
\hline & Dichotodione (177) & D. dichotoma & nd & [47] \\
\hline
\end{tabular}

\section{Diterpenes of Group III}

The diterpenes of this group are derived from cyclization of the geranyl-geraniol precursor between C-2 and C-10 or by ring contraction of the prenylated-germacrane [1]. Xenicane diterpenes, the main diterpenes of Group III, undergo oxidation, epoxidation, condensation, and other reactions to give rise to monocyclic, bicyclic, and tricyclic structures. Forty xenicane diterpenes were isolated from members of the genus Dictyota and most of them exhibited interesting biological activities, such as antiviral [16], anti-inflammatory [76], cytotoxic [12], antifungal [77], and other biological activities. Tables 7 and 8 summarize 55 diterpenes of Group III from Dictyota species (see in Section 4.1).

\subsection{Xenicane Diterpenes}

Xenicane diterpenes are a large class of marine diterpenes bearing a cyclononane ring as a common structural feature. The species of the genus Dictyota have been shown to be important producers of xenicane diterpenes since 40 xenicanes were isolated from members of this genus. Antiviral compounds, 179-183, were obtained from $D$. plectens from the South China Sea. Compound 181 showed moderate inhibition against HIV-1 replication with an $\mathrm{IC}_{50}$ value of $21.9 \pm 1.3 \mu \mathrm{M}$. Compound 183 displayed moderate antiviral activity against HA-mediated viral entry and strong anti-inflammatory activity against LPS-induced NO production at $10.0 \mu \mathrm{M}$ [16]. Compound $\mathbf{1 8 4}$ was isolated from D. plectens, collected from the Xuwen coast, China and was found to exhibit a weak anti-inflammatory activity against LPS-induced NO production at $10.0 \mu \mathrm{M}$ [76]. Two cytotoxic diterpenes, acetyldictyolal (185) and hydroxyacetyldictyolal (186), were isolated from $D$. dichotoma, collected at Oshoro Bay, Hokkaido [78]. Compound 185 displayed strong cytotoxicity against P-388, KB, NSCLCN6-L16 cell lines with $\mathrm{EC}_{50}$ values ranging from 1.50 to $9.1 \mu \mathrm{g} / \mathrm{mL}$ and weak antifungal activity against Aspergillus fumigates (IPC864-64), Microsporum canis (IPC1687-87) and Trichophyton mentagrophytes (IPC1468-83) [50]. Dictyodial (187) and $4 \alpha$-acetyldictyodial (188) were isolated from $D$. linearis, collected from the south 
coasts of Chios Island [38]. Compound 187 was also isolated from D. crenulata and D. flabellata, respectively. Compound 187 exhibited potent antibacterial activity against Staphylococcus aureus and Bacillus subtilis as well as antifungal activity against C. albicans [77]. Hydroxydictyodial (189), isolated from $D$. spinulosa collected from Kin, Okinawa was found to exhibit a potent antifeedant activity against the omnivorous fish Tilapia mossambica as well as antibiotic activity against S. aureus and B. subtilis [79]. Compound $\mathbf{1 9 0}$ was reported from D. divaricata from the Great Barrier Reef region of Northern Australia [27]. 17-Acetoxy-dictyodial (191), isolated from D. ciliolata collected from the Oualidia lagoon was found to exhibit moderate antifungal activity against $C$. albicans with MIC value of $50 \mu \mathrm{g} / \mathrm{mL}$ [80] (Figure 12).

Table 7. Bioactivities of xenicane diterpenes (179-218) from the genus Dictyota.

\begin{tabular}{|c|c|c|c|c|}
\hline Structure Class & Metabolites & Sources & Activities & References \\
\hline \multirow{10}{*}{$\begin{array}{l}\text { Monocyclic } \\
\text { diterpenes }\end{array}$} & $179-182$ & D. plectens, South China Sea & Antiviral activity & [16] \\
\hline & 183 & D. plectens, South China Sea & $\begin{array}{l}\text { Specific antiviral activity; } \\
\text { Strong anti-inflammatory activity }\end{array}$ & [16] \\
\hline & 184 & D. plectens, Xuwen coast, China & Weak anti-inflammatory activity & [76] \\
\hline & Acetyldictyolal (185) & D. dichotoma, Oshoro bay, Hokkaido & $\begin{array}{l}\text { High cytotoxicity; } \\
\text { Weak antifungal activity }\end{array}$ & {$[50,78]$} \\
\hline & Hydroxyacetyldictyolal (186) & $\begin{array}{l}\text { Dictyota sp., Le Brusc Lagoon. } \\
\text { D. dichotoma, Oshoro bay, Hokkaido }\end{array}$ & nd & {$[41,78]$} \\
\hline & Dictyodial (187) & $\begin{array}{l}\text { D. crenulata } \\
\text { D. flabellata } \\
\text { D. linearis, Chios Island }\end{array}$ & $\begin{array}{l}\text { Good antibiotic activity; } \\
\text { Antifungal activity }\end{array}$ & {$[38,77]$} \\
\hline & $4 \alpha$-Acetyldictyodial (188) & D. linearis, Chios Island & nd & [38] \\
\hline & Hydroxydictyodial (189) & D. spinulosa, Kin Okinawa & $\begin{array}{l}\text { Antibiotic activity; } \\
\text { Potent antifeedant }\end{array}$ & [79] \\
\hline & 190 & D. divaricata, Great Barrier Reef region & nd & [27] \\
\hline & 191 & D. ciliolata, Oualidia lagoon & Moderate antifungal activity & [80] \\
\hline \multirow{13}{*}{$\begin{array}{l}\text { Bicyclic } \\
\text { diterpenes }\end{array}$} & $\begin{array}{l}\text { Dictyotalides A-B }(192,193) \\
\text { Nordictyotalide (194) } \\
\text { 4-Acetoxydictyolactone (195) }\end{array}$ & D. dichotoma, Yagachi Okinawa & Significant cytotoxicity & [12] \\
\hline & $\begin{array}{l}\text { Isodictyohemiacetal (196) } \\
\text { Dictyodiacetal (197) }\end{array}$ & D. dichotoma, Oshoro bay, Hokkaido & nd & [78] \\
\hline & Dictyolactone (198) & D. dichotoma & $\begin{array}{l}\text { High algicidal activity; } \\
\text { Moderate insecticidal activity; } \\
\text { Weak antifungal activity; } \\
\text { Significant cytotoxicity }\end{array}$ & {$[29,50]$} \\
\hline & Neodictyolactone (199) & D. linearis, Chios Island & $\begin{array}{l}\text { Weak antifungal activity; } \\
\text { Cytotoxicity }\end{array}$ & {$[38,50]$} \\
\hline & 200 & D. plectens, Xuwen coast, China & $\begin{array}{l}\text { Antiviral activity; } \\
\text { Weak anti-inflammatory activity }\end{array}$ & [76] \\
\hline & 201-203 & D. plectens, Xuwen coast, China & Weak anti-inflammatory activity & [76] \\
\hline & 204 & D. plectens, Xuwen coast, China & $\begin{array}{l}\text { Specific antiviral activity; } \\
\text { Significant anti-inflammatory } \\
\text { activity }\end{array}$ & [76] \\
\hline & 205 & $\begin{array}{l}\text { D. plectens, Xuwen coast, China } \\
\text { Dictyota sp., Le Brusc Lagoon }\end{array}$ & $\begin{array}{l}\text { Antiviral activity; } \\
\text { Weak anti-inflammatory activity }\end{array}$ & {$[41,76]$} \\
\hline & 206 & D. plectens, South China Sea & Weak antiviral activity & [16] \\
\hline & 207,208 & Dictyota sp., Bahia de Los Angeles & nd & [81] \\
\hline & 209 & $\begin{array}{l}\text { Dictyota sp., Bangsaen Beach, } \\
\text { Thailand }\end{array}$ & Weak anti-tuberculosis activity & [32] \\
\hline & 210 & Dictyota spp., Mediterranean Sea & nd & [23] \\
\hline & $211-213$ & D. divaricata, Great Barrier Reef region & nd & [27] \\
\hline \multirow{4}{*}{$\begin{array}{l}\text { Tricyclic } \\
\text { diterpenes }\end{array}$} & 214 & D. divaricata, Great Barrier Reef region & nd & [40] \\
\hline & Ciliolatale (215) & D. ciliolata, Oualidia lagoon & nd & [80] \\
\hline & Dictyoepoxide (216) & Dictyota sp., Bahia de Los Angeles & $\begin{array}{l}\text { High vasopressin receptor } \\
\text { antagonist activity }\end{array}$ & [81] \\
\hline & $4 \alpha$-Hydroxycrenulatene (217) & $\begin{array}{l}\text { Dictyota sp., Bangsaen Beach, } \\
\text { Thailand }\end{array}$ & nd & [32] \\
\hline Bis-diterpene & Dictyotadimer A (218) & Dictyota sp., Mediterranean Sea & nd & [82] \\
\hline
\end{tabular}


Table 8. Bioactivities of crenulidane, dichotomane, and crenulane diterpenes (219-233) from the genus Dictyota.

\begin{tabular}{|c|c|c|c|c|}
\hline Structure Class & Metabolites & Sources & Activities & References \\
\hline \multirow{10}{*}{ Crenulidanes } & Crenulacetal A (219) & $\begin{array}{l}\text { D. dichotoma } \\
\text { D. spinulosa }\end{array}$ & nd & [83] \\
\hline & Crenulacetal B (220) & D. spinulosa, Yagachi Okinawa & nd & [83] \\
\hline & Crenulacetal C (221) & D. dichotoma, Nagahama beach, Ehime & Significant pesticide activity & [84] \\
\hline & Acetoxycrenulide (222) & $\begin{array}{l}\text { Dictyota spp., Mediterranean Sea } \\
\text { D. dichotoma, Troitsa Bay, Russian Far } \\
\text { East }\end{array}$ & $\begin{array}{l}\text { Weak anti-microfouling activity; } \\
\text { Strong fish antifeedant activity }\end{array}$ & {$[23,37,83,85]$} \\
\hline & 223 & $\begin{array}{l}\text { D. dichotoma, Troitsa Bay, Russian Far } \\
\text { East }\end{array}$ & nd & [37] \\
\hline & 224 & D. divaricata, Great Barrier Reef region & nd & [27] \\
\hline & 225 & D. divaricata & nd & [40] \\
\hline & 226,227 & D. plectens, South China Sea & Weak antiviral activity & [16] \\
\hline & $4 \alpha$-Hydroxypachylactone (228) & D. plectens, Xuwen coast, China & $\begin{array}{l}\text { Moderate anti-inflammatory } \\
\text { activity }\end{array}$ & [76] \\
\hline & Hydroxycrenulide (229) & Dictyota sp., Mediterranean Sea & Low antifouling activity & [41] \\
\hline \multirow[t]{2}{*}{ Dichotomanes } & Da-1 (230) & $\begin{array}{l}\text { D. menstrualis } \\
\text { D. pfaffii, Brazil }\end{array}$ & $\begin{array}{l}\text { Significant anti-HIV-1 activity; } \\
\text { Thrombin inhibitor; } \\
\text { Antifeedant effect; } \\
\text { Inhibitory against pasture weeds }\end{array}$ & [30,86-89] \\
\hline & AcDa-1 (231) & D. menstrualis, Brazil & Significant anti-HIV-1 activity & [85] \\
\hline \multirow{2}{*}{ Crenulanes } & Sanadaol (232) & D. dichotoma & High algicidal activity & [29] \\
\hline & Acetylsanadanol (233) & D. linearis, Chios Island & nd & [38] \\
\hline
\end{tabular}<smiles>[R]C1=CCC=C(C)CC([R])C(C(C)CCC=C(C)C)C1[R]</smiles>

$179 \mathrm{R}_{1}=\mathrm{CH}_{2} \mathrm{OH} \mathrm{R}_{2}=\mathrm{CH}_{2} \mathrm{OAc} \mathrm{R} \mathrm{R}_{3}=\mathrm{Me} \quad 182$ $180 \mathrm{R}_{1}=\mathrm{CH}_{2} \mathrm{OH} \mathrm{R}_{2}=\mathrm{CH}_{2} \mathrm{OH} \mathrm{R} \mathrm{R}_{3}=\mathrm{H}$

$181 \mathrm{R}_{1}=\mathrm{CH}_{2} \mathrm{OAc} \mathrm{R}_{2}=\mathrm{CHO} \mathrm{R}_{3}=\mathrm{OH}$

$183 \mathrm{R}_{1}=\mathrm{CHO} \mathrm{R}_{2}=\mathrm{CHO} \mathrm{R}_{3}=\mathrm{OH}$

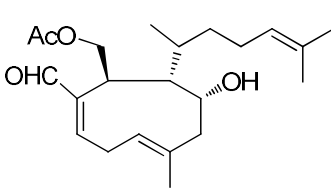

186

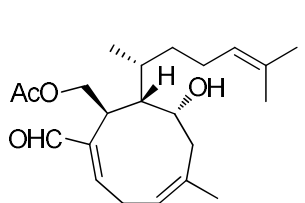

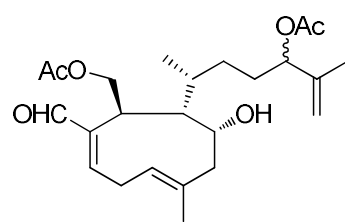

184<smiles>CC(=O)OC[C@H]1/C(C=O)=C\C/C=C(/C)CC[C@@H]1C(C)CCC=C(C)C</smiles>

185

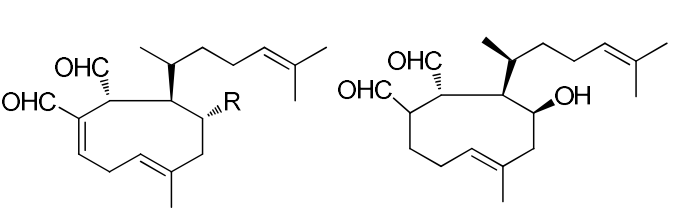

189<smiles>CC(=O)OC[C@H](CCC=C(C)C)[C@@H](CO)[C@@H](O)C/C(C)=C\C=C/C=O</smiles>

190

$188 \mathrm{R}=\mathrm{OAC}$<smiles>CC(=O)OC[C@H](CCC=C(C)C)[C@@H]1CC/C(C)=C\C/C=C(/C=O)[C@@H]1C</smiles>

191

Figure 12. Chemical structures of 179-191.

Four cytotoxic diterpenes, dictyotalide A (192), dictyotalide B (193), nordictyotalide (194), and 4-acetoxydictyolactone (195), isolated from D. dichotoma which was collected at Yagachi, Okinawa, exhibited significant cytotoxic activity against mouse melanoma cells (B16) with $\mathrm{IC}_{50}$ values of 2.57, $0.58,1.58$, and $1.57 \mu \mathrm{g} / \mathrm{mL}$, respectively [12]. Isodictyohemiacetal (196) and dictyodiacetal (197) were isolated from D. dichotoma, collected from Oshoro Bay, Hokkaido [78]. A rare algicidal diterpene, named dictyolactone (198), was reported from $D$. dichotoma. This compound showed high algicidal activity against representative harmful algal bloom (HAB) species Heterosigma akashiwo and Karenia mikimotoi, and moderate insecticidal activity against the dinoflagellate Alexandrium catenella [29]. 
Neodictyolactone (199) was isolated from D. linearis from the south coasts of Chios Island [38]. Both 198 and 199 displayed a weak antifungal activity against the fungal strains IPC864-64, IPC1687-87, and IPC1468-83 as well as excellent cytotoxicity against NSCLCN6-L16 cells with $\mathrm{EC}_{50}$ values of 0.3 and 2.0 $\mu \mathrm{g} / \mathrm{mL}$, respectively. Moreover, 198 showed significant cytotoxicity against P-388 cells, P-388/DOX cells, and $\mathrm{KB}$ cells with $\mathrm{EC}_{50}$ values of 2.8, 2.4, and $4.9 \mu \mathrm{g} / \mathrm{mL}$, while 199 was less active with $\mathrm{EC}_{50}$ values of 3.4, 3.9, and $6.2 \mu \mathrm{g} / \mathrm{mL}$, respectively [50]. Compounds 200-205 were isolated from D. plectens collected from the Xuwen coast. Compounds 200 and 205 showed an inhibitory effect on the replication of a wild-type HIV-1 with IC $_{50}$ values of 28.1 and $25.4 \mu \mathrm{M}$, respectively while 204 displayed moderate antiviral activity against HA-mediated viral entry with an inhibition rate of $66.8 \%$ at a concentration of $30.0 \mu \mathrm{M}$. Moreover, 204 exhibited significant anti-inflammatory effect by inhibiting LPS-induced NO production with an inhibition rate of $76.0 \%$ at a concentration of $10.0 \mu \mathrm{M}$ [76]. Compound 206 was isolated from D. plectens from the South China Sea. Compound 206 showed weak antiviral activity against HA-mediated viral entry [16]. Compounds 207 and 208 were reported from Dictyota sp. collected from Bahia de Los Angeles [81]. A rare anti-tuberculosis diterpene 209 was isolated from from Dictyota sp. collected from the Bang Saen Beach, Thailand and was found to display a weak anti-tuberculosis activity against Mycobacterium tuberculosis with an MIC value of $200 \mu \mathrm{g} / \mathrm{mL}$ [32]. Compound 210 was reported from Mediterranean Dictyota spp. collected from the Mediterranean coasts of Algeria [23]. Three novel xenicane diterpenes, compounds 211-213, were isolated from $D$. divaricata collected from the Great Barrier Reef region of Northern Australia [27] (Figure 13).

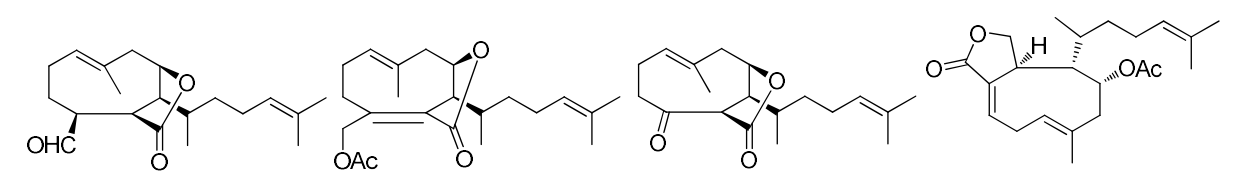<smiles>CC(C)=CCCC(C)C1CC(C)=CC=C2COCC21O</smiles>

196<smiles>[131In]</smiles>

194

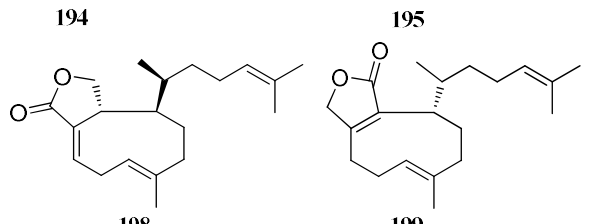

197

198

199

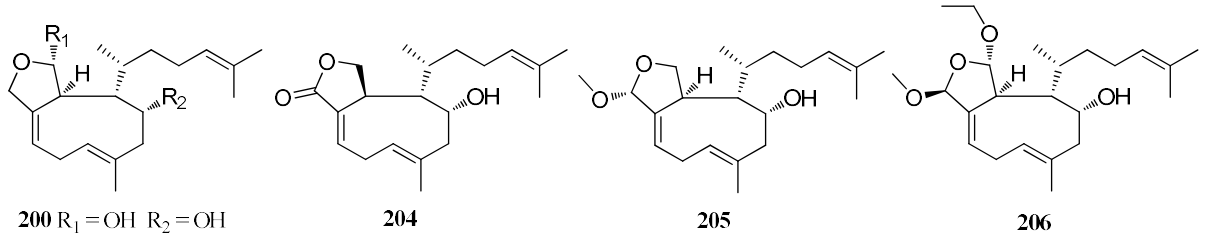

$200 \mathrm{R}_{1}=\mathrm{OH} \mathrm{R}_{2}=\mathrm{OH}$
$201 \mathrm{R}_{1}=\mathrm{OMe} \mathrm{\textrm {R } _ { 2 }}=\mathrm{OH}$

$\mathbf{2 0 2} \mathrm{R}_{1}=\mathrm{OH} \mathrm{R}_{2}=\mathrm{H}$
$\mathbf{2 0 3} \mathrm{R}_{1}=\mathrm{OMe} \mathrm{R} \mathrm{R}_{2}=\mathrm{H}$
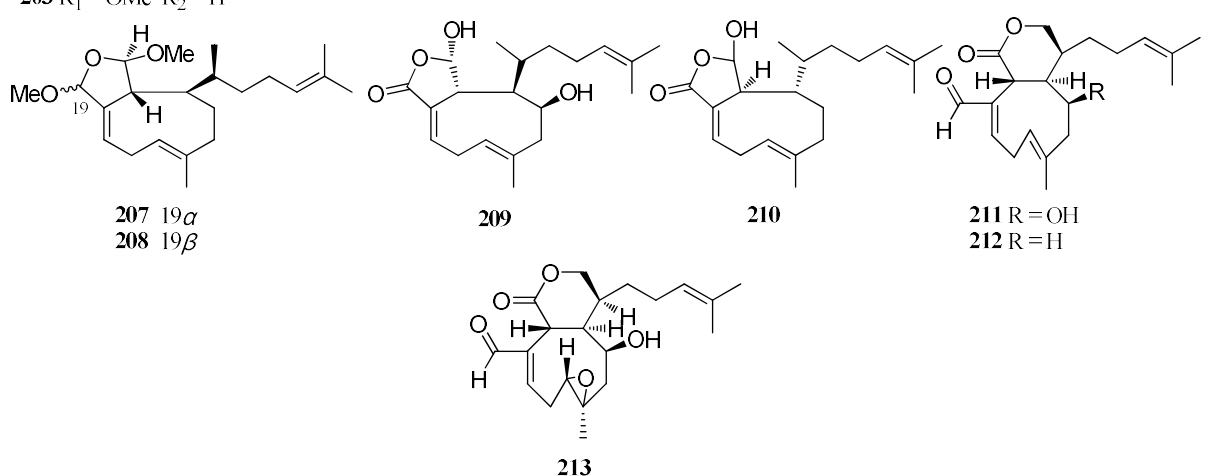

$212 \mathrm{R}=\mathrm{H}$

Figure 13. Chemical structures of 192-213.

A tricyclediterpene $\mathbf{2 1 4}$ was isolated from $D$. divaricata collected from the Great Barrier Reef region of Northern Australia [40] while ciliolatale (215) was isolated from D. ciliolata from the Oualidia 
lagoon [80]. A bioactive diterpene, named dictyoepoxide (216), was isolated from Dictyota sp. collected in Bahia de Los Angeles and was found to exhibit a high vasopressin receptor antagonist activity in vitro [81]. A tricyclediterpene, named $4 \alpha$-hydroxycrenulatane (217) was obtained from Dictyota sp. collected from Bang Saen Beach, Thailand [32] (Figure 14).

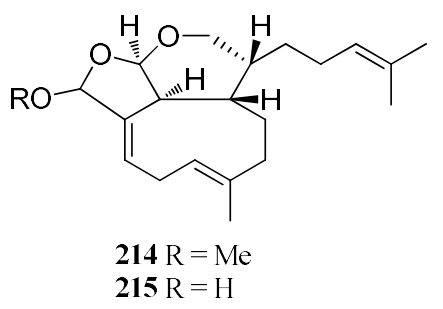

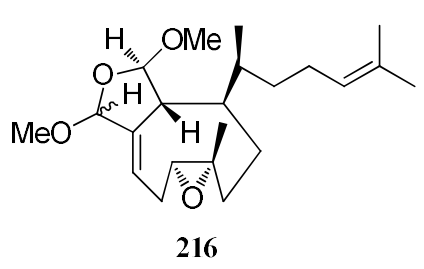

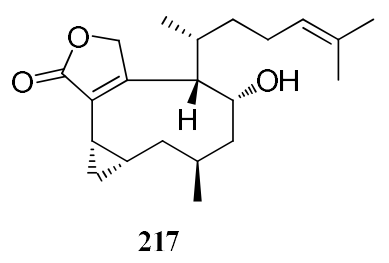

Figure 14. Chemical structures of compounds 214-217.

An unusual dissymmetrical dimer, dictyotadimer A (218) which contains two different xenicane units, was isolated from a Mediterranean brown seaweed Dictyota sp. Compound 218 is the first diterpene dimer of algal origin and a plausible biogenetic pathway of compound $\mathbf{2 1 8}$ has been proposed [82] (Figure 15).

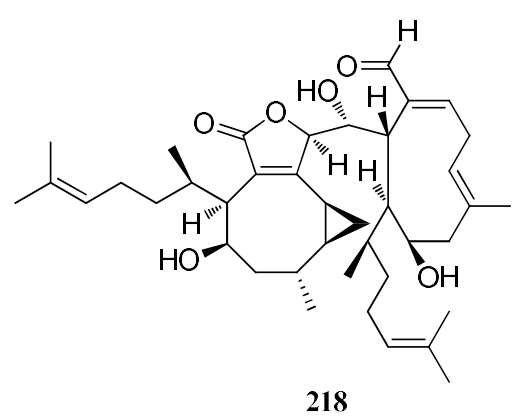

Figure 15. Chemical structure of 218.

\subsection{Crenulidane Diterpenes}

Two crenulidane diterpenes, named crenulacetal A (219) and crenulacetal B (220), were isolated from D. spinulosa [83]. Moreover 219, together with crenulacetal C (221), were also isolated from D. dichotoma $[83,84]$. Compound $\mathbf{2 2 1}$ displayed significant pesticidal activity against the larvae of Polydora websterii at a concentration of $1.5 \mathrm{ppm}$ [84]. A piscicidal diterpene, named acetoxycrenulide (222), was isolated from D. dichotoma [37], and from Mediterranean Dictyota spp. [23]. Compound 222 exhibited strong fish antifeedant activity due to its piscicidal activity [83]. Compound 222 also displayed an anti-microfouling activity against three marine bacterial strains D41, 4M6, and TC5 with $\mathrm{EC}_{50}$ values of $82 \pm 28,69 \pm 17$, and $154 \pm 20 \mu \mathrm{M}$, respectively [23]. Moreover, a total synthesis of 222 has been accomplished [85]. Compound 223 was isolated from D. dichotoma collected in Troitsa Bay of the Peter the Great Bay [37]. Two crenulidanes 224 and 225 were isolated from $D$. divaricata collected from the Great Barrier Reef region of Northern Australia, [27,40] while 226-228 were reported from D. plectens. Compounds $\mathbf{2 2 6}$ and $\mathbf{2 2 7}$ displayed weak antiviral activity by inhibition of HA-mediated viral entry at $30.0 \mu \mathrm{M}[16,76]$ while 228 showed a moderate anti-inflammatory effect by inhibiting LPS-induced NO production with an inhibition rate of $53.2 \%$ at a concentration of $10 \mu \mathrm{M}$ [76]. Hydroxycrenulide (229) was isolated from a Mediterranean Dictyota sp. Compound 229 showed weak antifouling activity against the marine bacterial strain D41 [41] (Figure 16). 


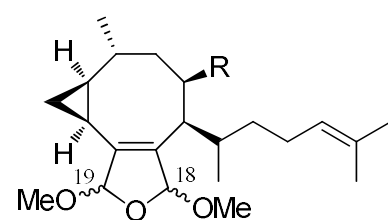

$219 \mathrm{R}=\mathrm{OH} 18 \beta \quad 19 \beta$

$220 \mathrm{R}=\mathrm{OH} \quad 18 \beta \quad 19 \alpha$

$221 \mathrm{R}=$ OAc $18 \alpha 19 \alpha$<smiles>CC(=O)OCC(CCC=C(C)C)[C@H]1C2=C(COC2=O)[C@@H]2CC2C(C)C[C@H]1O</smiles>

225<smiles>CC(=O)[C@]1([C@@H](C)CCC=C(C)C)C2=C(C(=O)OC2)[C@@H](C)[C@@H](C)[C@H](C)C[C@@H]1C</smiles>

222

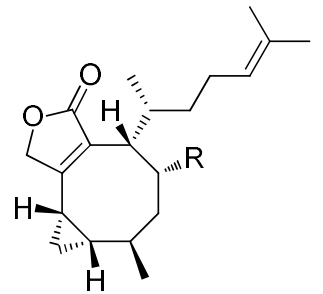

$226 \mathrm{R}=\mathrm{OAC}$

$228 \mathrm{R}=\mathrm{OH}$<smiles>CC(=O)O[C@H]1C[C@@H](C)[C@H]2C[C@H]2C2=C(COC2=O)[C@@H]1[C@H](C)C/C=C/C(C)(C)O</smiles>

223<smiles>CC(=O)O[C@H]1C[C@@H](C)[C@H](C)[C@H](C)C2=C([C@H](O)OC2=O)[C@H]1[C@H](C)CCC=C(C)C</smiles>

227<smiles>CC(=O)OC[C@H](CCC=C(C)C)[C@H]1C2=C(C[C@H]1C)C(=O)OC[C@H](C)C[C@H]2O</smiles>

224<smiles>CC(C)=CCCC(C)[C@H]1C2=C(C(=O)OC2)[C@H](C)[C@H](C)C[C@H]1C</smiles>

229

Figure 16. Chemical structures of 219-229.

\subsection{Dichotomane Diterpenes}

Two antiviral diterpenes, named Da-1 (230) and AcDa-1 (231), were isolated from D. menstrualis collected from Brazil. Compounds $\mathbf{2 3 0}$ and $\mathbf{2 3 1}$ exhibited significant antiretroviral activity against HIV-1 replication with $\mathrm{EC}_{50}$ values of 40 and $70 \mu \mathrm{M}$, respectively [86]. Compound 230 was also isolated from D. pfaffii and exhibited inhibitory activity against HSV-1 replication with an $\mathrm{EC}_{50}$ value of $5.10 \mu \mathrm{M}$ [87]. Additionally, 230 was found to display other bioactivities, including thrombin inhibition [30], anti-feeding activity [88], and herbicide activity against pasture weeds [89] (Figure 17).

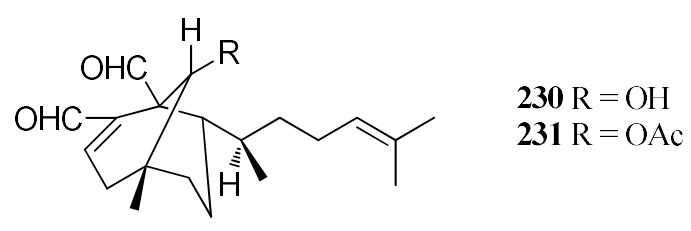

Figure 17. Chemical structures of 230-231.

\subsection{Crenulane Diterpenes}

An antialgal diterpene, named sanadaol (232), was isolated from D. dichotoma. Compound 232 showed high antialgal activity (>95\%) against the red-tide phytoplankton H. akashiwo and K. mikimotoi at a dose of 10-20 $\mu \mathrm{g} / \mathrm{mL}$ [29]. Another crenulane diterpene, acetylsanadaol (233), was identified from D. linearis from the south coasts of Chios Island [38] (Figure 18).

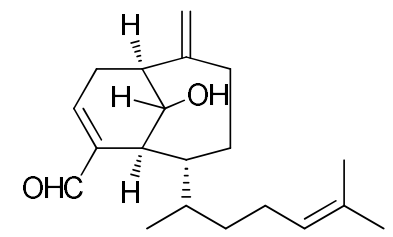

232

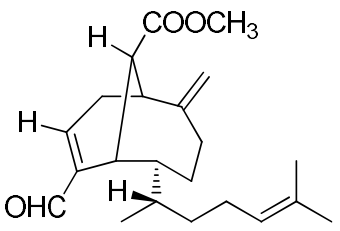

233

Figure 18. Chemical structures of 232-233. 


\section{Conclusions}

The genus Dictyota is a rich source of various natural products with unprecedented pharmacological and biological activities. Significant progress has been made in the discovery of bioactive secondary metabolites from members of the genus Dictyota [90]. The overwhelming majority of those secondary metabolites are diterpenes, especially Group II diterpenes (120 compounds) accounting for almost half of the total diterpenes from the Dictyota species (233 compounds). The cosmopolite $D$. dichotoma, the species that produces diterpenes of all three groups (I-III), has been proven to be an important producer of diterpenes. A total of 78 structurally diverse diterpenes have been isolated from $D$. dichotoma.

Some diterpene skeletons from Dictyota species are the characteristic constituents of this genus, which have chemotaxonomic significance. For example, the majority of prenylated-guaiane and dolabellane diterpenes were isolated from $D$. dichotoma, while dolastane diterpenes are mainly found in three species $D$. dichotoma, $D$. divaricato, and $D$. linearis. Xenicane diterpenes, a class of chemical characteristic for the taxonomy of the genus Dictyota, are found in only a few Dictyota species, mainly in D. plectens.

However, there are a number of problems in drug discovery and development from Dictyota species, including the development of new techniques applied to discover more bioactive diterpenes, total synthesis, multi-target screening assay, and pharmacological mechanisms of drug candidates. Firstly, it is necessary to discover more bioactive secondary metabolites from Dictyota species using a combined multi-target screening assay, bioassay-guided separation with an LC-MS based metabolomics approach in further research. Secondly, few results have been achieved in the total synthesis of bioactive diterpenes. The total synthesis of compounds $\mathbf{1 5 2}$ and $\mathbf{2 2 2}$ has been successfully completed. More efforts should be devoted in improving the total synthesis of bioactive diterpenes from the genus Dictyota. Successful total synthesis would be beneficial for the structural optimization of natural diterpenes, for further biological activity evaluation, and for pharmacological and clinical applications. Thirdly, as for bioactivity evaluation, less than half of the diterpenes derived from the Dictyota species have been measured due to the limitations of bioactivity assays. Various biological activity assays, including multi-target screening assay, in vitro and animal experiments, should be improved to promote the discovery of new promising leader drugs.

This review summarized diterpenes derived from the genus Dictyota up to the end of 2017, providing valuable insight into the further discoveries of novel diterpenes from the genus Dictyota.

Author Contributions: J.C. collected a complete survey of all compounds isolated from the genus Dictyota; J.C., H.L. and Z.Z. wrote the manuscript; J.Z. and X.Y. interpreted and revised the results, and wrote the manuscript; Z.Z., X.X. and B.L. discussed the results scientifically and contributed to editing of the paper.

Acknowledgments: This work was financially supported by the National Natural Science Foundation of China (41406163), the China Agriculture Research System (CARS-50), the Ningbo Marine Algae Biotechnology Team (2011B81007), the LiDakSum Marine Biopharmaceutical Development Fund, the National 111 Project of China, Synthesis of Biosurfactants from Seafood Processing Waste (CPR/17/101), Ningbo Public Service Platform for High-Value Utilization of Marine Biological Resources"(NBHY-2017-P2), the Scientific Research Foundation for Returned Scholars of ZJHRSS, and the K.C. Wong Magna Fund in Ningbo University.

Conflicts of Interest: The authors declare no conflict of interest.

\section{References}

1. Teixeira, V.L.; Kelecom, A. A chemotaxonomic study of diterpenes from marine brown algae of the genus Dictyota. Sci. Total Environ. 1988, 75, 271-283. [CrossRef]

2. Taylor, R.B.; Lindquist, N.; Kubanek, J.; Hay, M.E. Intraspecific variation in palatability and defensive chemistry of brown seaweeds: Effects on herbivore fitness. Oecologia 2003, 136, 412-423. [CrossRef] [PubMed] 
3. Ragan, M.A.; Jensen, A. Quantitative studies on brown algal phenols. I. Estimation of absolute polyphenol content of Ascophyllum nodosum (L.) le jol. and Fucus vesiculosus (L.). J. Exp. Mar. Biol. Ecol. 1977, 30, $209-221$. [CrossRef]

4. Bouzidi, N.; Daghbouche, Y.; El Hattab, M.; Aliche, Z.; Culioli, G.; Piovetti, L.; Garrigues, S.; de la Guardia, M. Determination of total sterols in brown algae by fourier transform infrared spectroscopy. Anal. Chim. Acta 2008, 616, 185-189. [CrossRef] [PubMed]

5. Martins, A.P.; Yokoya, N.S.; Colepicolo, P. Biochemical modulation by carbon and nitrogen addition in cultures of Dictyota menstrualis (dictyotales, phaeophyceae) to generate oil-based bioproducts. Mar. Biotechnol. 2016, 18, 314-326. [CrossRef] [PubMed]

6. Abdel-Fattah, A.F.; Hussein, M.D.; Fouad, S.T. Carbohydrates of the brown seaweed Dictyota dichotoma. Phytochemistry 1978, 17, 741-743. [CrossRef]

7. Gaysinski, M.; Ortalo-Magné, A.; Thomas, O.P.; Culioli, G. Extraction, purification, and NMR analysis of terpenes from brown algae. Methods Mol. Biol. 2015, 1308, 207-223. [PubMed]

8. Duh, C.Y.; Sheu, H.R. Cytotoxic cembranoids from the soft corals Sinularia gibberosa and Sarcophyton trocheliophorum. J. Nat. Prod. 1996, 59, 595-598. [CrossRef]

9. Reyes, F.; Ardá, A.; Martín, R.; Fernández, R.; Rueda, A.; Montalvo, D.; Gómez, C.; Jiménez, C.; Rodríguez, J.; Ma, S.J. New cytotoxic cembranes from the Sea Pen Gyrophyllum sibogae. J. Nat. Prod. 2004, 67, 1190-1192. [CrossRef] [PubMed]

10. Iwashima, M.; Matsumoto, Y.; Takahashi, H.; Iguchi, K. New marine cembrane-type diterpenoids from the okinawan soft coral Clavularia koellikeri. J. Nat. Prod. 2000, 63, 1647-1652. [CrossRef] [PubMed]

11. De-Paula, J.C.; Bueno, L.B.; Cavalcanti, D.N.; Yoneshigue-Valentin, Y.; Teixeira, V.L. Diterpenes from the brown alga Dictyota crenulata. Molecules 2008, 13, 1253-1262. [CrossRef] [PubMed]

12. Ishitsuka, M.O.; Kusumi, T.; Kakisawa, H. Antitumor xenicane and norxenicane lactones from the brown alga Dictyota dichotoma. J. Org. Chem. 1988, 53, 5010-5013. [CrossRef]

13. Barbosa, J.P.; Teixeira, V.L.; Pereira, R.C. A dolabellane diterpene from the brown alga Dictyota pfaffii as chemical defense against herbivores. Bot. Mar. 2004, 47, 147-151. [CrossRef]

14. Caamal-Fuentes, E.; Moo-Puc, R.; Freile-Pelegrin, Y.; Robledo, D. Cytotoxic and antiproliferative constituents from Dictyota ciliolata, Padina sanctae-crucis and Turbinaria tricostata. Pharm. Biol. 2014, 52, 1244-1248. [CrossRef] [PubMed]

15. Ayyad, S.E.; Makki, M.S.; Al-Kayal, N.S.; Basaif, S.A.; El-Foty, K.O.; Asiri, A.M.; Alarif, W.M.; Badria, F.A. Cytotoxic and protective DNA damage of three new diterpenoids from the brown alga Dictoyota dichotoma. Eur. J. Med. Chem. 2011, 46, 175-182. [CrossRef] [PubMed]

16. Cheng, S.; Zhao, M.; Sun, Z.; Yuan, W.; Zhang, S.; Xiang, Z.; Cai, Y.; Dong, J.; Huang, K.; Yan, P. Diterpenes from a Chinese collection of the brown alga Dictyota plectens. J. Nat. Prod. 2014, 77, 2685-2693. [CrossRef] [PubMed]

17. Siless, G.E.; García, M.; Pérez, M.; Blustein, G.; Palermo, J.A. Large-scale purification of pachydictyol a from the brown alga Dictyota dichotoma obtained from algal wash and evaluation of its antifouling activity against the freshwater mollusk Limnoperna fortunei. J. Appl. Phycol. 2017, 30, 629-636. [CrossRef]

18. De Rosa, S.; De Stefano, S.; Zavodnik, N. Hydroazulenoid diterpenes from the brown alga Dictyota dichotoma var. Implexa. Phytochemistry 1986, 25, 2179-2181. [CrossRef]

19. Nagle, D.G.; Sultana, G.N.N.; Schrader, K.K.; Hossain, C.F.; Stanikunaite, R.; Hamann, M.T.; Rajbandari, I. Secondary metabolites from plants and marine organisms as selective anti-cyanobacterial agents. ACS Symp. 2003, 848, 179-194.

20. Simas, D.L.R.; Kaiser, C.R.; Gestinari, L.M.; Duarte, H.M.; de Paula, J.C.; Soares, A.R. Diterpenes from the brown seaweed Dictyota caribaea (dictyotaceae, phaeophyceae): The ecological and taxonomic significance. Biochem. Syst. Ecol. 2014, 52, 33-37. [CrossRef]

21. Palermo, J.; Bernardo, J.; Seldes, A. In Dictyol-d-2-beta-acetate and other diterpenoids from the brown alga Dictyota dichotoma. An. Asoc. Quim. Argent. 1994, 82, 355-358.

22. Abou-El-Wafa, G.S.; Shaaban, M.; Shaaban, K.A.; El-Naggar, M.E.; Maier, A.; Fiebig, H.H.; Laatsch, H. Pachydictyols b and c: New diterpenes from Dictyota dichotoma Hudson. Mar. Drugs 2013, 11, 3109-3123. [CrossRef] [PubMed] 
23. Othmani, A.; Bouzidi, N.; Viano, Y.; Alliche, Z.; Seridi, H.; Blache, Y.; El Hattab, M.; Briand, J.-F.; Culioli, G. Anti-microfouling properties of compounds isolated from several Mediterranean Dictyota spp. J. Appl. Phycol. 2013, 26, 1573-1584. [CrossRef]

24. Choi, B.W.; Lee, H.S.; Lee, K.B.; Lee, B.H. Isolation of diacyl glycerol acyl transferase (DGAT) inhibitors from Pachydictyon coriaceum. Phytother. Res. 2011, 25, 1041-1045. [CrossRef] [PubMed]

25. König, G.M.; Wright, A.D.; Sticher, O.; Rüegger, H. Four new hydroazulenoid diterpenes from the tropical marine brown alga Dictyota volubilis. Planta Med. 1993, 59, 174-178. [CrossRef] [PubMed]

26. Pathirana, C.; Andersen, R.J. Diterpenoids from the brown alga Dictyota binghamiae. Can. J. Chem. 1984, 62, 1666-1671. [CrossRef]

27. König, G.M.; Wright, A.D.; Sticher, O. New xenicane and hydroazulenoid diterpenes from an Australian collection of Dictyota divaricata. Tetrahedron 1991, 22, 1399-1410. [CrossRef]

28. Alarado, A.B.; Gerwick, W.H. Dictyol h, a new tricyclic diterpenoid from the brown seaweed Dictyota dentata. J. Nat. Prod. 2004, 48, 132-134. [CrossRef]

29. Kim, J.Y.; Alamsjah, M.A.; Hamada, A.; Fujita, Y.; Ishibashi, F. Algicidal diterpenes from the brown alga Dictyota dichotoma. Biosci. Biotechnol. Biochem. 2014, 70, 2571-2574. [CrossRef]

30. Pereira, R.C.; Lourenco, A.L.; Terra, L.; Abreu, P.A.; Laneuville Teixeira, V.; Castro, H.C. Marine diterpenes: Molecular modeling of thrombin inhibitors with potential biotechnological application as an antithrombotic. Mar. Drugs 2017, 15, 79. [CrossRef] [PubMed]

31. Wright, A.D.; Koenig, G.M.; Sticher, O. New and highly oxidised hydroazulenoid diterpenes from the tropical marine brown alga Dictyota volubilis. Tetrahedron 1993, 49, 571-580. [CrossRef]

32. Jongaramruong, J.; Kongkam, N. Novel diterpenes with cytotoxic, anti-malarial and anti-tuberculosis activities from a brown alga Dictyota sp. J. Asian Nat. Prod. Res. 2007, 9, 743-751. [CrossRef] [PubMed]

33. König, G.M.; Wright, A.D.; Nys, R.D.; Sticher, O. A diterpene from the marine brown alga Dictyota bartayresii. Phytochemistry 1992, 31, 2541-2542. [CrossRef]

34. Gedara, S.R.; Abdelhalim, O.B.; Elsharkawy, S.H.; Salama, O.M.; Shier, T.W.; Halim, A.F. Cytotoxic hydroazulene diterpenes from the brown alga Dictyota dichotoma. Z. Naturforsch. C. Biosci. 2003, 58, 17-22. [CrossRef]

35. Hardt, I.H.; Fenical, W.; Cronin, G.; Hay, M.E. Acutilols, potent herbivore feeding deterrents from the tropical brown alga, Dictyota acutiloba. Phytochemistry 1996, 43, 71-73. [CrossRef]

36. Ayyad, S.E.; Abdel-Halim, O.B.; Shier, W.T.; Hoye, T.R. Cytotoxic hydroazulene diterpenes from the brown alga Cystoseira myrica. Z. Naturforsch. C Biosci. 2003, 58, 33-38. [CrossRef]

37. Kolesnikova, S.A.; Lyakhova, E.G.; Kalinovsky, A.I.; Dmitrenok, P.S.; Dyshlovoy, S.A.; Stonik, V.A. Diterpenoid hydroperoxides from the far-eastern brown alga Dictyota dichotoma. Aust. J. Chem. 2009, 62, 1185-1188. [CrossRef]

38. Siamopoulou, P.; Bimplakis, A.; Iliopoulou, D.; Vagias, C.; Cos, P.; Vanden Berghe, D.; Roussis, V. Diterpenes from the brown algae Dictyota dichotoma and Dictyota linearis. Phytochemistry 2004, 65, 2025-2030. [CrossRef] [PubMed]

39. Sun, H.H.; Fenical, W. Hydroxydilophol, a new monocyclic diterpenoid from the brown alga Dictyota masonii. J. Org. Chem. 1979, 10, 1354-1356. [CrossRef]

40. König, G.M.; Wright, A.D.; Sticher, O. Diterpenes from the brown alga Dictyota divaricata. Phytochemistry 1991, 30, 3679-3682. [CrossRef]

41. Viano, Y.; Bonhomme, D.; Camps, M.; Briand, J.F.; Ortalomagné, A.; Blache, Y.; Piovetti, L.; Culioli, G. Diterpenoids from the mediterranean brown alga Dictyota sp. Evaluated as antifouling substances against a marine bacterial biofilm. J. Nat. Prod. 2009, 72, 1299-1304. [CrossRef] [PubMed]

42. Ishitsuka, M.O.; Ichikawa, A.; Kusumi, T.; Kakisawa, H. Existence of a termite soldier diterpene-like substances in the dictyotaceae algae. Symp. Chem. Natl. Prod. 1988, 188-195. [CrossRef]

43. Kolesnikova, S.A.; Kalinovsky, A.I.; Fedorov, S.N.; Shubina, L.K.; Stonik, V.A. Diterpenes from the far-eastern brown alga Dictyota dichotoma. Phytochemistry 2006, 67, 2115-2119. [CrossRef] [PubMed]

44. Amico, V.; Currenti, R.; Oriente, G.; Piattelli, M.; Tringali, C. 18-hydroxy 3,7-dolabelladiene from the brown alga, Dictyota dichotoma. Phytochemistry 1981, 20, 848-849. [CrossRef]

45. Tringali, C.; Oriente, G.; Piattelli, M.; Nicolosi, G. Structure and conformation of two new dolabellane-based diterpenes from Dictyota sp. J. Nat. Prod. 1984, 47, 615-619. [CrossRef] [PubMed] 
46. Pardo-Vargas, A.; de Barcelos Oliveira, I.; Stephens, P.R.; Cirne-Santos, C.C.; de Palmer Paixao, I.C.; Ramos, F.A.; Jimenez, C.; Rodriguez, J.; Resende, J.A.; Teixeira, V.L.; et al. Dolabelladienols a-c, new diterpenes isolated from Brazilian brown alga Dictyota pfaffii. Mar. Drugs 2014, 12, 4247-4259. [CrossRef] [PubMed]

47. Khan, A.M. An update of terpenoids, steroids and biodiversity of seaweeds from the coasts of Pakistan. J. Chem. Soc. Pak. 2010, 32, 379-395.

48. Ireland, C.; Faulkner, D.J. Diterpenes from Dolabella californica. J. Org. Chem. 1977, 42, 3157-3162. [CrossRef] [PubMed]

49. Cai, X.H.; Wang, Y.Y.; Zhao, P.J.; Li, Y.; Luo, X.D. Dolabellane diterpenoids from Aglaia odorata. Phytochemistry 2010, 71, 1020-1024. [CrossRef] [PubMed]

50. Bouaïcha, N.; Tringali, C.; Pesando, D.; Malléa, M.; Roussakis, C.; Verbist, J.F. Bioactive diterpenoids isolated from Dilophus ligulatus. Planta Med. 1993, 59, 256-258. [CrossRef] [PubMed]

51. Rao, C.B.; Pullaiah, K.C.; Surapaneni, R.K.; Sullivan, B.W.; Albizati, K.F.; Faulkner, D.J.; He, C.; Clardy, J. The diterpenes of Dictyota dichotoma from the Indian ocean. J. Org. Chem. 1987, 18, 2736-2742. [CrossRef]

52. Rao, C.B.; Trimurtulu, G.; Sreedhara, C.; Rao, D.V.; Bobzin, S.C.; Faulkner, D.J. Diterpenes from the brown alga Dictyota bartayresiana. Phytochemistry 1994, 37, 509-513. [CrossRef]

53. Wright, A.D.; König, G.M.; Sticher, O. Two new dolabellane derivatives from the brown alga Dictyota pardarlis. Tetrahedron 1990, 46, 3851-3858. [CrossRef]

54. Wright, A.D.; König, G.M.; Sticher, O. New dolabellane derivatives from the brown alga Dictyota pardalis. Helv. Chim. Acta 1991, 74, 1801-1807. [CrossRef]

55. König, G.M.; Wright, A.D. New dolabellanes from the marine alga Dictyota pardalis f. Pseudohamata. Tetrahedron 1994, 50, 8011-8018. [CrossRef] 
56. Stephens, P.R.S.; Cirne-Santos, C.C.; de Souza Barros, C.; Teixeira, V.L.; Carneiro, L.A.D.; Amorim, L.D.S.C.; Ocampo, J.S.P.; Castello-Branco, L.R.R.; de Palmer Paixão, I.C.N. Diterpene from marine brown alga Dictyota friabilis as a potential microbicide against HIV-1 in tissue explants. J. Appl. Phycol. 2016, 29, 775-780. [CrossRef]

57. Barbosa, J.P.; Pereira, R.C.; Abrantes, J.L.; Cirne dos Santos, C.C.; Rebello, M.A.; Frugulhetti, I.C.; Texeira, V.L. In vitro antiviral diterpenes from the brazilian brown alga Dictyota pfaffii. Planta Med. 2004, 70, 856-860. [CrossRef] [PubMed]

58. Soares, D.C.; Calegari-Silva, T.C.; Lopes, U.G.; Teixeira, V.L.; de Palmer Paixao, I.C.; Cirne-Santos, C.; Bou-Habib, D.C.; Saraiva, E.M. Dolabelladienetriol, a compound from Dictyota pfaffii algae, inhibits the infection by Leishmania amazonensis. PLoS Negl. Trop. Dis. 2012, 6, e1787. [CrossRef] [PubMed]

59. Ioannou, E.; Quesada, A.; Rahman, M.M.; Gibbons, S.; Vagias, C.; Roussis, V. Dolabellanes with antibacterial activity from the brown alga Dilophus spiralis. J. Nat. Prod. 2011, 74, 213-222. [CrossRef] [PubMed]

60. Crews, P.; Klein, T.E.; Hogue, E.R.; Myers, B.L. Tricyclic diterpenes from the brown marine algae Dictyota divaricata and Dictyota linearis. J. Org. Chem. 1982, 13, 811-815. [CrossRef]

61. Kelecom, A.; Teixeira, V.L. Dolastane diterpenes from the marine brown alga Dictyota cervicornis. Phytochemistry 1988, 27, 2907-2909. [CrossRef]

62. Ali, M.S.; Pervez, M.K. Ring-a hydroxylated dolastanes from the marine brown alga Dictyota dichotoma (HUDS.) lamour. Nat. Prod. Res. 2003, 17, 281-286. [CrossRef] [PubMed]

63. Ahma, V.U.; Parveen, S.; Bano, S.; Shaikha, W.; Shameela, M. Dolastane diterpenoids from the brown alga Dictyota indica. Phytochemistry 1991, 30, 1015-1018. [CrossRef]

64. Garcia, D.G.; Bianco, E.M.; Santos Mda, C.; Pereira, R.C.; Faria, M.V.; Teixeira, V.L.; Burth, P. Inhibition of mammal $\mathrm{Na}^{+} \mathrm{K}^{+}$-ATPase by diterpenes extracted from the Brazilian brown alga Dictyota cervicornis. Phytother. Res. 2009, 23, 943-947. [CrossRef] [PubMed]

65. Dos Santos, A.O.; Britta, E.A.; Bianco, E.M.; Ueda-Nakamura, T.; Filho, B.P.; Pereira, R.C.; Nakamura, C.V. 4-acetoxydolastane diterpene from the Brazilian brown alga Canistrocarpus cervicornis as antileishmanial agent. Mar. Drugs 2011, 9, 2369-2383. [CrossRef] [PubMed]

66. Bianco, É.M.; Rogers, R.; Teixeira, V.L.; Pereira, R.C. Antifoulant diterpenes produced by the brown seaweed Canistrocarpus cervicornis. J. Appl. Phycol. 2008, 21, 341-346. [CrossRef]

67. Bianco, E.M.; Teixeira, V.L.; Pereira, R.C.; de Souza, A.M.; Nucci, P.; Afonso, I.F.; Rodrigues, C.R.; Castro, H.C. Brown seaweed defensive chemicals: A structure-activity relationship approach for the marine environment. Nat. Prod. Commun. 2009, 4, 173-178. [PubMed]

68. De Souza Barros, C.; Cirne-Santos, C.C.; Garrido, V.; Barcelos, I.; Stephens, P.R.S.; Giongo, V.; Teixeira, V.L.; de Palmer Paixão, I.C.N. Anti-HIV-1 activity of compounds derived from marine alga Canistrocarpus cervicornis. J. Appl. Phycol. 2015, 28, 2523-2527. [CrossRef]

69. Sun, H.H.; Mcconnell, O.J.; Fenical, W.; Hirotsu, K.; Clardy, J. Tricyclic diterpenoids of the dolastane ring system from the marine alga Dictyota divaricata. Tetrahedron 1981, 37, 1237-1242. [CrossRef]

70. Ochi, M.; Watanabe, M.; Kido, M.; Ichikawa, Y.; Miura, I.; Tokoroyama, T. Amijidictyol, a new diterpenoid from the brown seaweed Dictyota linearis: X-ray crystal and molecular structure. Chem. Lett. 1980, 16, 1233-1234. [CrossRef]

71. Begley, M.J.; Pattenden, G.; Robertson, G.M. Synthetic radical chemistry. Total synthesis of ( \pm )-isoamijiol. J. Chem. Soc. Perkin Trans. 1988, 46, 1085-1094. [CrossRef]

72. Dunlop, R.W.; Ghisalberti, E.L.; Jefferies, P.R.; Skelton, B.W.; White, A.H. Structure of a new dolastane diterpene from Dictyota furcellata. Aust. J. Chem. 1989, 42, 315-319. [CrossRef]

73. González, A.G.; Martiń, J.D.; Norte, M.; Rivera, P.; Perales, A.; Fayos, J. Structure and absolute configurations of Dictyota sp. Diterpenes. Tetrahedron 1983, 39, 3355-3357. [CrossRef]

74. Teixeira, V.L.; Tomassini, T.; Kelecom, A. Cervicol, a further secodolastane diterpene from the marine brown alga Dictyota cervicornis küzing (Phaeophyceae, Dictyotaceae). Bull. Soc. Chim. Belg. 1986, 95, $263-268$. [CrossRef]

75. Bano, S.; Parveen, S.; Ahmad, V.U. Marine natural products, XIV secodolastane diterpenoids of Dictyota indica from the Arabian sea. J. Nat. Prod. 1990, 53, 492-495. [CrossRef]

76. Zhao, M.; Cheng, S.; Yuan, W.; Dong, J.; Huang, K.; Sun, Z.; Yan, P. Further new xenicanes from a Chinese collection of the brown alga Dictyota plectens. Chem. Pharm. Bull. 2015, 63, 1081-1086. [CrossRef] [PubMed] 
77. Finer, J.; Clardy, J.; Fenical, W.; Minale, L.; Riccio, R.; Battaile, J.; Kirkup, M.; Moore, R.E. Structures of dictyodial and dictyolactone, unusual marine diterpenoids. J. Org. Chem. 1979, 44, 2044-2047. [CrossRef]

78. Enoki, N.; Ishida, R.; Matsumoto, T. Structures and conformations of new nine-membered ring diterpenoids from the marine alga Dictyota dichotoma. Chem. Lett. 1982, 11, 1749-1752. [CrossRef]

79. Tanaka, J.; Higa, T. Hydroxydictyodial, a new antifeedant diterpene from the brown alga Dictyota spinulosa. Chem. Lett. 1984, 2, 231-232. [CrossRef]

80. Manzo, E.; Ciavatta, M.L.; Bakkas, S.; Villani, G.; Varcamonti, M.; Zanfardino, A.; Gavagnin, M. Diterpene content of the alga Dictyota ciliolata from a Moroccan lagoon. Phytochem. Lett. 2009, 2, 211-215. [CrossRef]

81. Patil, A.D.; Berry, D.; Brooks, D.P.; Hemling, M.E.; Kumar, N.V.; Mitchell, M.P.; Ohlstein, E.H.; Westley, J.W. A diterpene epoxide from the marine brown alga Dictyota sp.: Possible vasopressin V1 receptor antagonist. Phytochemistry 1993, 33, 1061-1064. [CrossRef]

82. Viano, Y.; Bonhomme, D.; Ortalo-Magné, A.; Thomas, O.P.; Hattab, M.E.; Piovetti, L.; Blache, Y.; Culioli, G. Dictyotadimer a, a new dissymmetric bis-diterpene from a brown alga of the genus Dictyota. Tetrahedron Lett. 2011, 52, 1031-1035. [CrossRef]

83. Kusumi, T.; Muanza-Nkongolo, D.; Goya, M.; Ishitsuka, M.; Iwashita, T.; Kakisawa, H. Structures of crenulacetals a, b, c, and d. The new diterpenoids from the brown algae of Dictyotaceae. J. Org. Chem. 1986, 17, 384-387. [CrossRef]

84. Takikawa, M.; Uno, K.; Ooi, T.; Kusumi, T.; Akera, S.; Muramatsu, M.; Mega, H.; Horita, C. Crenulacetal c, a marine diterpene, and its synthetic mimics inhibiting Polydora websterii, a harmful lugworm damaging pearl cultivation. Chem. Pharm. Bull. 1998, 29, 462-466. [CrossRef]

85. Wang, T.Z.; Emmanuel Pinard, A.; Paquette, L.A. Asymmetric synthesis of the diterpenoid marine toxin (+)-acetoxycrenulide. J. Am. Chem. Soc. 1996, 118, 1309-1318. [CrossRef]

86. Pereira, H.S.; Leao-Ferreira, L.R.; Moussatche, N.; Teixeira, V.L.; Cavalcanti, D.N.; Costa, L.J.; Diaz, R.; Frugulhetti, I.C. Antiviral activity of diterpenes isolated from the Brazilian marine alga Dictyota menstrualis against human immunodeficiency virus type 1 (HIV-1). Antivir. Res. 2004, 64, 69-76. [CrossRef]

87. Abrantes, J.L.; Barbosa, J.; Cavalcanti, D.; Pereira, R.C.; Frederico Fontes, C.L.; Teixeira, V.L.; Moreno Souza, T.L.; Paixao, I.C. The effects of the diterpenes isolated from the Brazilian brown algae Dictyota pfaffii and Dictyota menstrualis against the herpes simplex type-1 replicative cycle. Planta Med. 2010, 76, 339-344. [CrossRef] [PubMed]

88. Pereira, R.C.; Cavalcanti, D.N.; Teixeira, V.L. Effects of secondary metabolites from the tropical Brazilian brown alga Dictyota menstrualis on the amphipod Parhyale hawaiensis. Mar. Ecol. Prog. Ser. 2000, 205, 95-100. [CrossRef]

89. Fonseca, R.R.; Filho, A.P.; Villaça, R.C.; Teixeira, V.L. Inhibitory effects against pasture weeds in Brazilian amazonia of natural products from the marine brown alga Dictyota menstrualis. Nat. Prod. Commun. 2013, 8 , 1669-1672. [PubMed]

90. Blunt, J.W.; Copp, B.R.; Keyzers, R.A.; Munro, M.H.G.; Prinsep, M.R. Marine natural products. Nat. Prod. R. 2017, 34, 235-294. [CrossRef] [PubMed]

(C) 2018 by the authors. Licensee MDPI, Basel, Switzerland. This article is an open access article distributed under the terms and conditions of the Creative Commons Attribution (CC BY) license (http://creativecommons.org/licenses/by/4.0/). 